Comprehensive Summaries of Uppsala Dissertations

from the Faculty of Science and Technology xxx

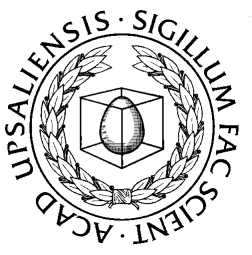

\title{
Soft X-ray emission spectroscopy of liquids and lithium battery materials
}

BY

ANDREAS AUGUSTSSON

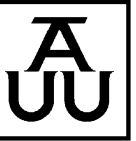

ACTA UNIVERSITATIS UPSALIENSIS

UPPSALA 2004 
Dissertation for the Degree of Doctor of Philosophy in Physics presented at Uppsala University to be publicaly examnined in the lecture hall (1111) at MIC Polacksbacken, on October 4, 2004, at 10.15 a.m. The examination will be conducted in English.

\section{Abstract}

Augustsson, A., 2004. RIXS studies of lithium inserted systems, Acta Universitatis Upsaliensis. Comprehensive Summaries of Uppsala Dissertations from the Faculty of Science and Technology. 684. 53 pp. Uppsala. ISBN 91-554-xxxx-xx.

Lithium ion insertion into electrode materials is commonly used in rechargeable battery technology. The insertion implies changes in both the crystal structure and the electronic structure of the electrode material. Side-reactions may occur on the surface of the electrode which is exposed to the electrolyte and form a solid electrolyte interface (SEI). The understanding of these processes is of great importance for improving battery performance. The chemical and physical properties of water and alcohols are complicated by the presence of strong hydrogen bonding. Various experimental techniques have been used to study geometrical structures and different models have been proposed to view the details of how these liquids are geometrically organized by hydrogen bonding. However, very little is known about the electronic structure of these liquids, mainly due to the lack of suitable experimental tools. In this thesis examples of studies of lithium battery electrodes and liquid systems using soft x-ray emission spectroscopy will be presented. Monochromatized synchrotron radiation has been used to accomplish selective excitation, in terms of energy and polarization. The electronic structure of graphite electrodes has been studied, before and after lithium intercalation. Changes in the electronic structure upon lithiation due to transfer of electrons into the graphite $\pi$-bands have been observed. Transfer of electrons in to the $3 \mathrm{~d}$ states of transition metal oxides upon lithiation have been studied, through low energy excitations as $d d$ - and charge transfer-exciations. A SEI was detected on cycled graphite electrodes. By the use of selective excitation different carbon sites were probed in the SEI. The local electronic structure of water, methanol and mixtures of the two have been examined using a special liquid cell, to separate the liquid from the vacuum in the experimental chamber. Results from the study of liquid water showed a strong influence on the $3 \mathrm{a}_{1}$ molecular orbital and orbital mixing between water molecules upon hydrogen bonding. Apart from the four-hydrogen-bonding structure in water, a structure where one hydrogen bond is broken could be separated and identified. The soft x-ray emission study of methanol showed the existence of ring and chain formations in the liquid phase and the dominating structures are formed of 6 and 8 molecules. Upon mixing of the two liquids, a segregation at the molecular level was found and the formation of new structures, which could explain the unexpected low increase of the entropy.

Andreas Augustsson, Department of Physics, Uppsala University, Box 530, SE-751 21

Uppsala, Sweden

(C) Andreas Augustsson 2004

ISSN 1104-232X

ISBN 91-554-5222-1 
Printed in Sweden by Universitetstryckeriet Uppsala University, Uppsala 2004 



\section{List of papers}

This thesis is based on a collection of articles listed below. Each paper will be referred to the text by its Roman numeral.

I. Solid Electrolyte Interphase on Graphite Li-ion Battery Anodes Studied by Soft X-ray Spectroscopy

A. Augustsson, M. Herstedt, J.-H. Guo, K. Edström G. V. Zhuang, P. N. Ross Jr, J.-E. Rubensson and J. Nordgren

Phys. Chem. Chem. Phys. 6, 2004, 4185

II. The electronic structure of $\mathrm{LiC}_{6}$ studied by RIXS

A. Augustsson, J.-H. Guo, C. M. Lee, P. N. Ross Jr, J.-E. Rubensson and J. Nordgren

In manuscript

III. Lithium Ion Insertion in Nanoporous Anatase $\mathrm{TiO}_{2}$ Studied with RIXS

A. Augustsson, A. Henningsson, J.-H. Guo, S. M. Butorin H. Siegbahn and J. Nordgren

J. Chem. Phys. 119, 2003, 3983

IV. Resonant soft x-ray emission spectroscopy of lithium battery electrodes based on vanadium-oxide nanotubes

A. Augustsson, T. Schmitt, L.-C. Duda, J. Nordgren, S. Nordlinder, K. Edström, T. Gustafsson, and J.-H. Guo

J. Appl. Phys. 94, 2003, 5083

V. The Redox Behavior of Vanadium Oxide Nanotubes Studied by X-ray Photoelectron Spectroscopy and Soft X-ray Absorption Spectroscopy

S. Nordlinder, A. Augustsson, T. Schmitt, J.-H. Guo, L.-C. Duda, J. Nordgren, T. Gustafsson, and K. Edström

Chem. Matter. 15, 2003, 3227

VI. Li-insertion into $\mathrm{V}_{6} \mathrm{O}_{13}$ battery cathodes studied by soft X-ray spectroscopy

T. Schmitt, A. Augustsson, L.-C. Duda, J. Nordgren, J. Höwing, and T. Gustafsson

J. Appl. Phys. 95, 2004, 6444

VII. Electronic Structure of Li-inserted $\mathbf{V}_{6} \mathbf{O}_{13}$ Battery Cathodes: Rigid Band Behavior and Effects of Hybridization

T. Schmitt, A. Augustsson, J. Nordgren, L.-C. Duda, J. Höwing, T. Gustafsson, U. Schwingenschlögl, and V. Eyert

Submitted to Appl. Phys. Lett. 
VIII. X-ray emission spectroscopy of Hydrogen bonding and Electronic Structure of Liquid Water

J.-H. Guo, Y. Luo, A. Augustsson, J.-E. Rubensson, C. Såthe, H. Ågren, H. Siegbahn and J. Nordgren

Phys. Rev. Lett. 89, 2002, 137402

IX. Local structures of liquid water studied by x-ray emission spectroscopy

S. Kashtanov, A. Augustsson, Y. Luo, J.-H. Guo, J.-E. Rubensson, C. Såthe, H. Ågren, H. Siegbahn and J. Nordgren

Phys. Rev. B 69, 2004, 024201-1

X. Molecular Structure of Alcohol-Water Mixtures

J.-H. Guo, Y. Luo, A. Augustsson, S. Kashtanov, J.-E. Rubensson, D. Shuh, H. Ågren and J. Nordgren

Phys. Rev. Lett. 94, 2003, 157401-1

XI. Resonant soft x-ray emission of solids and liquids

L.-C. Duda, T. Schmitt, A. Augustsson, and J. Nordgren

J. Alloys Comp. 362, 2004, 116

XII. Resonant soft-x-ray emission spectroscopy applied to liquids

J.-H. Guo, A. Augustsson, C.-J. Englund, and J. Nordgren

AIP Conf. Proc. 705, 2004, 1066

XIII. The molecular structure of alcohol-water mixtures determined by soft-X-ray absorption and emission spectroscopy

J. -H. Guo, Y. Luo, A. Augustsson, S. Kashtanov, J. -E. Rubensson, D. Shuh, V. Zhuang, P. Ross, H. Ågren, and J. Nordgren

J. Electron Spectrosc. Relat. Phenom. 137-140, 2004, 425

XIV. Resonant Inelastic X-ray Scattering at the Ti L Edge of Doped Strontium Titanates

A. Augustsson, J-E. Rubensson, C. Såthe, S. M. Butorin, J. Nordgren, J. -H. Guo, R. Meyer, R. Waser, J. L üning, S. Eisebitt, W. Ederhardt, A. Agui, D. D. Sarma

In manuscript

Reprints were made with permission from the publisher. 
The following articles have been omitted from the thesis. They were omitted either due to the character of the material, or due to the limited extent of my contribution.

- Bandlike and excitonic states of oxygen in $\mathrm{CuGeO}_{3}$ : Observation using polarized resonant soft $\mathrm{x}$-ray emission spectroscopy

L.-C. Duda, J. Downes, C. McGuinness, T. Schmitt, A. Augustsson, K.E. Smith, G. Dhalenne, and A. Revcolevschi

Phys. Rev. B 61, 2000, 4186

- Resonant Soft X-ray Emission Spectroscopy of $\mathrm{V}_{2} \mathrm{O}_{3}, \mathrm{VO}_{2}$ and $\mathrm{NaV}_{2} \mathrm{O}_{5}$

T. Schmitt, L.-C. Duda, A. Augustsson, J.-H. Guo, J. Nordgren, J. E. Downes, C. Macguinness, K. E. Smith, G. Dhalenne, A. Revcolevschi, M. Klemm, and S. Horn

Surface Rev. and Lett. 9, 2002, 1369

- Electronic Structure of $\mathrm{GaAs}_{1-x} \mathrm{~N}_{x}$ Alloy by Soft-X-ray Absorption and Emission: Origin of the Ruduced Optical Efficiency

V. N. Strocov, P.O. Nilsson, A. Augustsson, T. Schmitt, D. DebowskaNilsson, R. Claessen, Yu. Egorov, V. M. Ustinov and ZH. I. Alferov

phys stat. sol. 233, 2002, R1-R3

- Nitrogen local electronic structure in $\mathrm{Ga}(\mathrm{In}) \mathrm{AsN}$ alloys by soft-xray absorption and emission: Implications for optical properties V. N. Strocov, P. O. Nilsson, T. Schmitt, A. Augustsson, L. Gridneva, D. Debowska-Nilsson, R. Claessen, A. Yu. Egorov, V. M. Ustinov, and Zh. I. Alferov

Phys. Rev. B 69, 2004, 035206

- Resonant Soft X-ray emission spectroscopy of doped and undoped vanadium oxides

T. Schmitt, L.-C. Duda, M. Matsubara, A. Augustsson, F. Trif, J.-H. Guo, L. Gridneva, T. Uozumi, A. Kotani, and J. Nordgren

J. Alloys Comp. 362, 2004, 143

- Electronic structure studies of $\mathrm{V}_{6} \mathrm{O}_{13}$ by soft X-ray emission spectroscopy: band-like and excitonic vanadium states

T. Schmitt, L.-C. Duda, M. Matsubara, M. Mattesini, M. Klemm, A. Augustsson, J.-H. Guo, T. Uozumi, S. Horn, R. Ahuja, A. Kotani, and J. Nordgren

Phys. Rev. B 69, 2004, 125103

- Resonant Inelastic Soft X-ray Scattering at Hollow Lithium States in Solid LiCl

M. Agåker, J. Söderström, T. Käämbre, C. Glover, L. Gridneva, T. Schmitt, A. Augustsson, M. Mattesini, R. Ahuja, and J.-E. Rubensson

Phys. Rev. Lett. 93, 2004, 016404 
- Electronic structure of nanostructured $\mathrm{ZnO}$ from X-ray absorption and emission spectroscopy and LDA calculations

C. L. Dong, C. Persson, L. Vayssieres, A. Augustsson, T. Schmitt, M. Matesini, R. Ahuja, C. L. Chang, and J.-H. Guo

Submitted to Phys. Rev. B

- Study of the defects in $\mathrm{ZnO}$ nanorods by means of soft-x-ray absorption and emission spectroscopy

C. L. Dong, C. Persson, A. Augustsson, T. Schmitt, M. Mattesini, L. Vayssieres, S. Mao, R. Ahuja, C. L. Chang, and J.-H. Guo

In manuscript

- Electron Correlation and Charge Transfer in $\left[\left(\mathrm{Ba}_{0.9} \mathrm{Nd}_{0.1}\right) \mathrm{CuO}_{2+d}\right] 2 /\left[\mathrm{CaCuO}_{2}\right] 2$ Superconducting Superlattices

B. Freelon, A. Augustsson, J.-H. Guo, P. G. Medaglia, A. Tebano, and G. Balestrino

Submitted to Phys. Rev. Lett.

- Electronic Structure of Alkali Carbonates ( $\mathrm{Li}, \mathrm{Na}, \mathrm{K}$ and $\mathrm{Cs}$ ) as studied by X-Ray Absorption and Emission Spectroscopies

G. V. Zhuang, C. L. Dong, A. Augustsson, B. Brena, C. L. Chang, Y. Luo, J. Nordgren, J.-H. Guo, and P. N. Ross

Submitted to J. Electron Spectrosc. Relat. Phenom.

- The interaction of cations and liquid water studied by soft-ray emission spectroscopy

J.-H. Guo, A. Augustsson, S. Kashtanov, D. Spångberg, J. Nordgren, K. Hermansson, and Y. Luo

Submitted to J. Electron Spectrosc. Relat. Phenom.

- X-ray absorption and selectively excited X-ray Emission Spectra of Atenolol and Nadolol

Johan Söderström, Johan Gråsjö, Stepan Kashtanov, Christel Bergström, Marcus Agåker, Thorsten Schmitt, Andreas Augustsson, Laurent Duda, Jinghua Guo, Joseph Nordgren, Luo Yi, Per Artursson and Jan-Erik Rubensson

Submitted to J. Electron Spectrosc. Relat. Phenom.

\section{Comments on my participation}

Experimental studies performed at synchrotron facilities, as is most of the work presented here, are often an effort of many people, which is also reflected by the 
lengthy author lists. My contribution to the papers has been on the experimental side, as well as in the analysis, discussions and writing of the papers. I have taken part in all the experiments except paper III and VI. The chemical preparation of the battery related samples were made by others. 


\section{Contents}

$\begin{array}{ll}\text { Introduction } & 13\end{array}$

1 Soft X-ray Spectroscopy $\quad 15$

1.1 X-ray absorption . . . . . . . . . . . . . . . . . 15

1.2 X-ray emission . . . . . . . . . . . . . . . . 16

1.3 Resonant x-ray emission and RIXS . . . . . . . . . . . . 17

1.4 Theoretical description of RIXS . . . . . . . . . . . . . . . . 19

1.5 Duration time for RIXS and nuclear motion . . . . . . . . . . . 19

2 Experimental 21

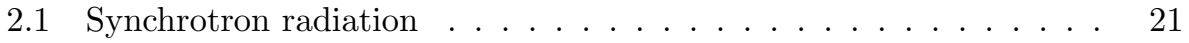

2.2 Soft X-ray Emission Spectrometer . . . . . . . . . . . . . 23

2.3 The Liquid cell . . . . . . . . . . . . . . . . . . . . . . 25

2.4 Sample preparations of Battery electrodes . . . . . . . . . . 26

2.4.1 Graphite and $\mathrm{LiC}_{6} \ldots \ldots \ldots \ldots \ldots$

2.4.2 Graphite electrodes/SEI . . . . . . . . . . . . . . 26

2.4.3 Anatase $\mathrm{Li}_{x} \mathrm{TiO}_{2} \ldots \ldots \ldots \ldots \ldots \ldots$

2.4.4 Vanadium nanotubes . . . . . . . . . . . . . . 27

3 Results 29

3.1 Rechargeable lithium batteries . . . . . . . . . . . . . . 29

3.1.1 The Anode: Graphite electrodes . . . . . . . . . . . . . 29

3.1 .2 Graphite . . . . . . . . . . . . . . . 29

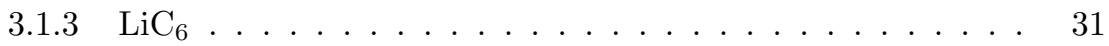

3.1.4 The formation of the SEI layer . . . . . . . . . . . . 32

3.1.5 Summary Graphite Anodes . . . . . . . . . . . . . . 36

3.1.6 The Cathode: Transition Metal Oxides . . . . . . . . . 37

3.1 .7 Nanoporous Anatase $\mathrm{TiO}_{2} \ldots \ldots \ldots \ldots$. . . . . . . . 37

3.1 .8 Vanadium Oxide Nanotubes . . . . . . . . . . . . . . . . . 39

3.1.9 Lithium insertion into $\mathrm{V}_{6} \mathrm{O}_{13}$ cathodes . . . . . . . . . 41

3.1 .10 Phospho-olivines $\mathrm{LiFePO}_{4} \ldots \ldots \ldots \ldots$. . . . . . . 41

3.2 Liquids . . . . . . . . . . . . . . . . . . . . . 41

3.2 .1 Liquid water and methanol . . . . . . . . . . . 42

3.2 .2 Mixing of liquids and solutions . . . . . . . . . . . 43 
3.2.3 Detuning: Resonant Soft x-ray emission of water below the threshold . . . . . . . . . . . . . . . . . 44 44

$\begin{array}{ll}\text { Acknowledgements } & 45\end{array}$

4 Summery in Swedish $\quad 47$

4.1 Mjukröntgenspektroskopi av litium batterier och vätskor . . . . . . 47

$\begin{array}{ll}\text { Bibliography } & 50\end{array}$ 


\section{Introduction}

Spectroscopic techniques are traditionally used for investigating the energy distribution of electronic states (electronic structure) in atoms, molecules and solid state materials. The techniques are based on the interaction of particles/waves and the electrons surrounding the atoms, either by exciting the system or removing an electron from the system. The system is disturbed by the incoming radiation or particles and the response depend on the energy/wave-length of incoming particles. Photons in the Soft-x-ray spectral region (20 eV to $5 \mathrm{keV})$ are well matched for reaching core level resonances in most elements. For lighter elements the inner most energy level (1s) is reached and for heavier elements one could use the second or even third level, as $2 \mathrm{p}$ and $3 \mathrm{~d}$, which are still considered core levels for elements with $3 \mathrm{~d}$ and $4 \mathrm{f}$ outer most electronic levels, respectively. Core levels of different elements have specific energies and are well separated from each other. These core levels may shift in energy depending on the chemical environment of the atoms. But the largest effect is felt by the outer most electronic states (valence electrons) in the atoms as they will rearrange upon chemical bonding between atoms. The bonding mechanism between atoms in molecules, between molecules and other condensed materials can be of different character, depending on the strength and the type of interaction. The electronic structure of atoms, molecules and complex materials are understood and modelled in terms of Quantum mechanics.

The work in this thesis show the possibility to also study liquids and wet systems using soft x-ray spectroscopy. The thesis is divided into two parts, where a study of various lithium battery materials is presented followed by studies of common liquids as water and methanol.

Batteries are an important part of our daily life. With the wide use of portable electronics, e.g. cellular phones and laptop computers, there is a high demand for small efficient rechargeable power sources. Lithium-ion batteries have been on the market since the beginning of the 1990s and are currently responsible for the highest sale value for small rechargeable cells. There are several advantages with this system, as the high voltage, high energy density and long retention or (shelf)selflife. Transition metal (TM) oxides (such as $\mathrm{LiMn}_{2} \mathrm{O}_{4}, \mathrm{LiNiO}_{2}$ ) [25] are typically used as cathode (the positive electrode) material and the anode (the negative electrode) is normally carbon/graphite. The most common electrolytes are mixtures of alkyle carbonates, for example, ethylene carbonate (EC) and propylene carbonate $(\mathrm{PC})$, and lithium salts such as $\mathrm{LiClO}_{4}$ and $\mathrm{LiPF}_{6}$. The $\mathrm{Li}^{+}$-ions act as charge carriers between the electrodes during charge and discharge processes. Insertion of lithium ions basically implies doping of electrons into the electrode material (see 


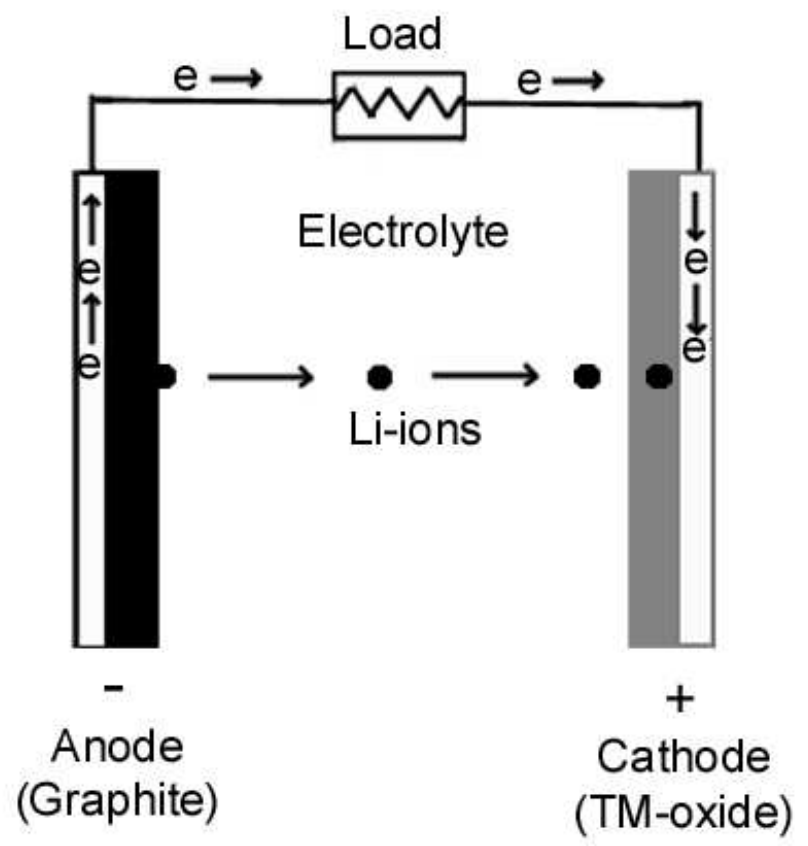

Figure 1: Schematic illustration of the discharge process in a Li-ion battery.

Fig. 1). In the case of TM-oxides this implies doping of electrons into the empty 3d-states. Lithiation of graphite implies a near rigid filling of electrons into the graphite $\pi$-bands. During charge and discharge chemical reactions take place on the surface of the electrode leading to formation of a Solid Electrolyte Interface (SEI) layer [30]. SEI layers have been found both on the anode and the cathode. The performance of graphite as an anode in rechargeable batteries is largely determined by this SEI layer. Studies of several TM-oxide cathodes are presented, where the lithiation process is monitored. Electronic structure studies of lithium intercalation into graphite is presented and the possibility of using resonant x-ray emission to determine the SEI layer formed on graphite anodes.

The chemical and physical properties of water and alcohols are complicated by the presence of strong hydrogen bonding. Many models have been proposed to view the details of how these liquids are geometrically organized by hydrogen bonding and various experimental techniques have been used to study geometrical structures. However, very little is known about the electronic structure of these liquids, mainly due to the lack of suitable experimental tools. These liquids, with high vapor pressure, can not be kept, at ambient pressure and temperature, inside the required vacuum environment, as they will evaporate instantly. But lately there have been a number of reports how to overcome this problem and in this thesis an "easy" way how to do Soft-x-ray emission spectroscopy of liquids is presented. 


\section{Chapter 1}

\section{Soft X-ray Spectroscopy}

\section{$1.1 \quad$ X-ray absorption}

In x-ray absorption spectroscopy (XAS) the intensity distribution of core hole states is studied (see left panel in figure 1.1). XAS yields valuable information about the unoccupied states, and chemical composition can also be determined. The atomic nature of the core hole implies elemental and chemical state selectivity. If the incoming photon has the exact energy required to move a core electron to an unoccupied state an excitation may occur i.e the atom may absorb the incoming photon (x-ray photon). The probability of such a transition determine the x-ray absorption cross section. The decay of the core excited states can occur through two channels: nonradiative (Auger) decay and radiative (emission) decay. In the soft x-ray region, Auger electron yield usually takes up more than $99 \%$ that leaves less than $1 \%$ to x-ray fluorescence yield. Cascade excitation and Auger decay results in low energy electrons that can emerge from the sample. The electrons can be detected by measuring a drain current or by e.g. a channeltron. The intensity of these secondary Auger electrons or the photons can be measured as a function of incoming photon energy. This will reflect the absorption cross section as the intensity of the secondary electrons/emitted photons are approximately proportional to the absorbed intensity. Because of the short mean free path of electrons this method is very surface sensitive. If instead the out going photons are detected (fluorescence yield), the x-ray absorption is more bulk probing (about 1000-2000 A) due to the comparatively larger attenuation lengths. The XAS process is governed by dipole selection rules. In the case of atoms, the angular momentum number has to change by one, $\Delta l= \pm 1$, the z-component $(m)$ of the orbital momentum has to change by $\Delta m= \pm 1,0$ and the spin (s) has to be conserved, $\Delta s=0$. For example, for the carbon atom, while scanning over $\mathrm{C} 1 \mathrm{~s}$ thresh-hold the $\mathrm{C}$ p states are probed.

In graphite, sheets of $\mathrm{sp}^{2}$-hybridized carbon atoms arrange in hexagonal rings extended in two dimensions (graphene sheets). These $\mathrm{sp}^{2}$-hybridized carbons form $\pi$ and $\sigma$ bonds. It is possible to separate $\pi$ and $\sigma$ states of oriented materials (as graphite) by using linear polarized light and angle resolved XAS, which have been 


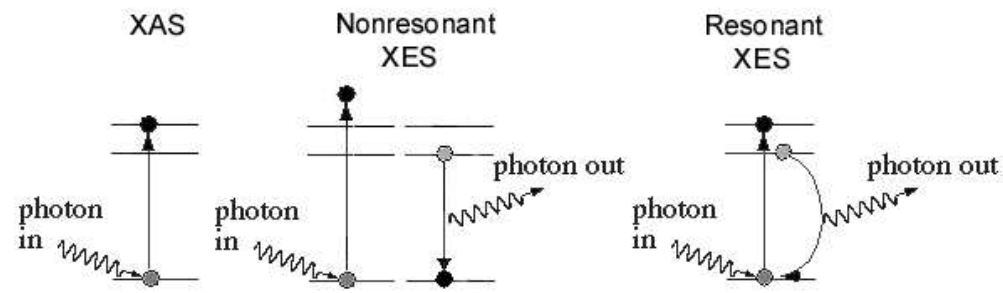

Figure 1.1: Illustration of the x-ray processes. x-ray absorption, Nonresonant x-ray emission and Resonant x-ray emission.

used in paper I. When the polarization vector of the light is parallel to the c-axis of graphite (perpendicular to the graphite planes) the $\pi$ states are selected and, when the polarization vector is perpendicular to the c-axis the $\sigma$ states are preferably selected. A more general and detailed description of the x-ray absorption spectroscopy can be found in the book by J. Stöhr [41].

\section{$1.2 \quad \mathrm{X}$-ray emission}

In $\mathrm{x}$-ray emission spectroscopy (XES) the intensity distribution of $\mathrm{x}$-rays from the sample is measured. X-rays are emitted when a valence electron fills a core vacancy (core hole), see middle panel in figure 1.1. The atomic like nature of the core hole makes XES elemental and site selective. Due to the large attenulation lengths (photons) the method is bulk sensitive. By virtue of dipole selection rules XES has orbital and symmetry selectivity ability.

In non-resonant XES (conventional x-ray emission) the excitation is such that the core electron is removed leaving the system ionized. The subsequent x-ray decay process can be described independently to the excitation process, i.e. the excitation and the decay can be viewed as a two-step process. The x-ray emission can be described as spontaneous emission of photons in a transition that are allowed by the dipole selection rules between two electronic states. The implication of the dipole selection rules depends on the type of system, atom, molecule or solid. For the atom the rules are stringent as stated above (in XAS). In molecules the selection rules are modified, and the electronic structure can be modelled with wave functions as linear combinations of atomic orbitals (LCAO). The selection rules can be exemplified by the water molecule $\left(\mathrm{H}_{2} \mathrm{O}\right)$. As described in paper VIII, the water molecule has the electronic configuration $1 a_{1}^{2} 2 a_{1}^{2} 1 b_{2}^{2} 3 a_{1}^{2} 1 b_{1}^{2}$. The x-ray emission spectra of the water molecule is dominated by transitions from occupied 2 p-derived orbitals $1 b_{2}, 3 a_{1}$ and $1 b_{1}$ to the oxygen 1 s core hole $\left(1 a_{1}\right)$. All three orbitals have the same occupation number (2 electrons in each orbital), but $1 \mathrm{~b}_{2}$ and $3 \mathrm{a}_{1}$ are derived from mixing of oxygen $2 \mathrm{p}$ with hydrogen 1 s atomic orbitals whereas $1 b_{1}$ has almost pure oxygen $2 p$ character. This fact is reflected in the $\mathrm{x}$-ray emission spectrum of water, where the $1 \mathrm{~b}_{2}$ and $3 \mathrm{a}_{1}$ orbitals give less intensity compared to $1 b_{1}$ because they have less oxygen $2 p$-character. The almost pure oxygen $2 \mathrm{p}$ character of the $1 \mathrm{~b}_{1}$ orbital implies large $\mathrm{x}$-ray intensities for transitions to the oxygen $1 s$ orbital. 
In a solid the discrete states of atoms are better described by continuous bands, so the x-ray intensities are governed by the occupied density-of-states (DOS). In the case of K-emission, where a 1s hole is created, only states with $p$-character are allowed to decay and partial p-type density of states (PDOS) is thereby measured.

\subsection{Resonant x-ray emission and RIXS}

One of the advantages by using tunable monchromatized synchrotron radiation is the ability of chemical state selectivity. The binding energy of the core level is strongly influenced by the chemical environment. Thus, the position of the absorption (XAS) threshold is also influenced by the chemical environment. But the measured XAS spectrum is a superposition of spectra of the different species in the sample. In normal x-ray emission, the obtained spectrum can also be viewed as superposition of emission from different species. By tuning the excitation energy to a certain feature in the absorption spectra, it's chemical state can be selected. Note, that this requires that the absorption features of the atomic species are separated in energy, which is not always the case.

With the use of tunable monochromatized synchrotron radiation resonance phenomena have shown to occur when tuning the excitation energy close to the core threshold, which can not be explained by a two-step description [20]. It was shown that the coherence in the process can be important. The absorptionemission event must be regarded as a one-step process, also sometimes referred as Resonant Inelastic Scattering Soft X-ray Scattering (RIXS) process.

Resonant x-ray emission of molecules have symmetry selection rules where the parity is conserved in the absorption-emission process i.e. the parity of the initial and the final state have to be the same. This is valid if the molecule has either odd or even inversion symmetry of the spacial coordinates of the wave functions, and the energy separation of the intermediate states are larger than the energy spread of the exciting radiation and, the width of the intermediate states have to be smaller than their separation. But, then forbidden transitions can occur even if the molecule has inversion symmetry, because vibrational modes can couple with excited states of different parity during the lifetime of the core excited state, s.k. Vibronic coupling. This breaking of the symmetry can be recovered by large energy detuning, which will be discussed in section 1.5 in the context of fast dissociation.

The excitation dependence of the x-ray emission of HOPG graphite as well as diamond is successfully understood using a scattering approach $[3,4,22,39]$. The dependence on excitation energy is related to the presence of crystallographic structure induced electronic structure ordering in the system. The fluorescence spectra can be interpreted within the RIXS formalism for the band structure of graphite, where the momentum is conserved in the resonant inelastic scattering process $[21,22]$. The scattering process can be viewed as a vertical optical transition between the valence and the conduction band. A specific excitation energy selects a conduction band at a particular point in the Brillouin Zone (BZ). Emission will occur from those critical points on the valence band, that have the same momentum as the selected conduction band. The momentum conservation process can be written as 


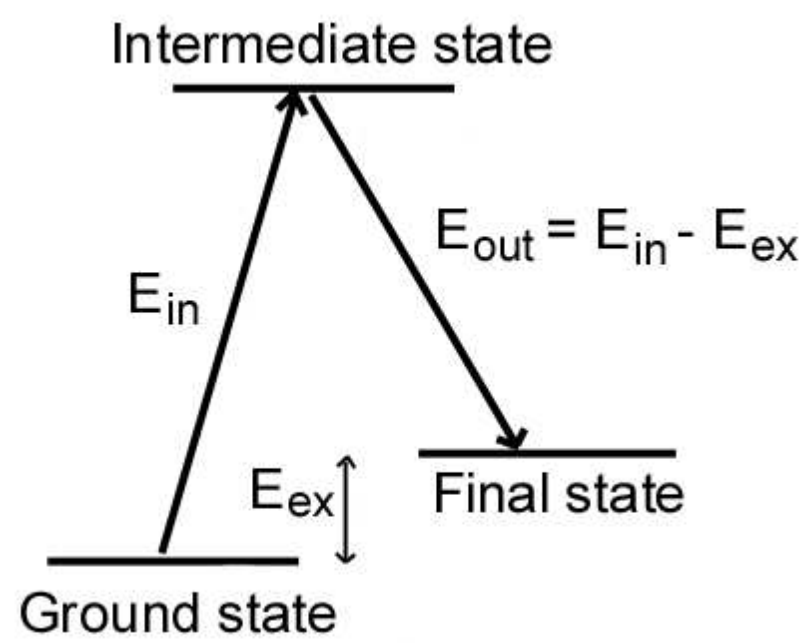

Figure 1.2: Illustration of the RIXS process, were $E_{\text {in }}$ and $E_{\text {out }}$ are energy of the incoming and outgoing photon, respectively. The energy of the final state is $E_{e x}$ above the ground state, and this state will appear as an energy-loss peak $E_{\text {ex }}$ below the excitation energy.

$$
k_{v}+q_{\text {in }}=k_{c}+q_{\text {out }}+\mathbf{G},(1)
$$

where $k_{v}$ is the momentum of the electron in the valence band and $k_{c}$ is the momentum of the electron in the conduction band. The momentum of the incoming and outgoing photons are $q_{i n}$ and $q_{\text {out }}$, and $\mathbf{G}$ is the reciprocal lattice vector. The momenta of soft x-ray photons (the wavelength is of the order of $40 \AA$ ) are small compared to the size of the BZ and can therefore be neglected. This reduces equation (1) to $k_{v}=k_{c}+\mathbf{G}$. Thus there is no appreciable momentum transfer in the coherent scattering process for soft x-rays.

3d-transition-metal (TM) compounds, such as titanium dioxide, are regarded as strongly correlated materials. In these systems, atomic-like discrete excitations must be considered. The electronic structure is often described in terms of lowenergy $d d-(\mathrm{d}$ to $\mathrm{d}$ ) and charge-transfer (CT) excitations $[2,17]$. The electron is localized at the excitation site, which is not the case with broad-band materials. The energy conservation applies to the whole scattering process, and one obtains information about the ground state of the system via intermediate core excited states. The energy conservation requires that $E_{\text {out }}=E_{\text {in }}-E_{\text {ex }},(2)$ where $E_{\text {out }}$ and

$E_{i n}$ are the energies of the outgoing and incoming photons, respectively. $E_{e x}$ is the excitation energy of the final state (See figure 1.2). The energy of the intermediate state does not enter into the equation which implies that the spectral broadening is not related to the life time of the intermediate state as in normal emission. Apart from the final state broadening, the resolution is set by the the experimental resolution i.e. the excitation source (width of $E_{i n}$ ) and the spectrometer resolution. Figure 1.2 shows that the energy of the outgoing x-ray, $E_{\text {out }}$, increases linearly with the energy of the incoming x-ray. The final state has the same parity as 
the initial state, due to the two dipole transitions and therefore $d d$-excitations are not forbidden. These dipole forbidden $d d$-transitions are observed in optical spectroscopy, via vibronic coupling, but very week in intensity.

\subsection{Theoretical description of RIXS}

The theoretical description of the RIXS process is based on how electromagnetic radiation interacts with electrons, and is described in terms of pertubation theory. After some derivations, best described in the book by J. Sakurai [35], one ends up with the Kramers-Heisenberg scattering formula for the cross section,

$$
\begin{gathered}
\frac{d^{2} \sigma}{d \Omega d \omega_{2}} \propto \frac{\omega_{2}}{\omega_{1}} \sum_{f} \mid \frac{e^{2}}{2 m c^{2}}\left\langle f\left|\mathbf{A}_{2} \cdot \mathbf{A}_{1}\right| i\right\rangle \\
+\left.\frac{e}{m c} \sum_{m}\left[\frac{\left\langle f\left|\mathbf{p}_{2} \cdot \mathbf{A}_{2}\right| m\right\rangle\left\langle m\left|\mathbf{p}_{1} \cdot \mathbf{A}_{1}\right| i\right\rangle}{E_{i}-E_{m}+\hbar \omega_{1}-\frac{i \Gamma_{m}}{2}}+\frac{\left\langle f\left|\mathbf{p}_{2} \cdot \mathbf{A}_{2}\right| m\right\rangle\left\langle m\left|\mathbf{p}_{1} \cdot \mathbf{A}_{1}\right| i\right\rangle}{E_{i}-E_{m}-\hbar \omega_{2}}\right]\right|^{2} \\
\times \delta\left(E_{i}-E_{f}+\hbar \omega_{1}-\hbar \omega_{2}\right)
\end{gathered}
$$

which is the linear approximation of the differential cross-section for x-ray scattering, where $i, m$ and $f$ are the wave functions of the initial, intermediate and final states, with energies $\mathrm{E}_{i}, \mathrm{E}_{m}$ and $\mathrm{E}_{f}$. The incident photon energy is represented by $\hbar \omega_{1}$ and $\hbar \omega_{2}$ represent the scattered photon energy after the scattering event. $\Gamma_{m}$ is the core-hole life time width of the intermediate states and $d \Omega$ is the solid angle element. The dipole operator is represented by the vector potential A times the momentum vector $\mathbf{p}$ of the electron. The first term in the equation describes the elastic x-ray scattering, the second and third term describes the resonant and non-resonant (anomalous) inelastic scattering, respectively. The second (resonant) term resonates for $\hbar \omega_{1}=\mathrm{E}_{m}-\mathrm{E}_{i}$, which occurs at or close to the absorption threshold.

\subsection{Duration time for RIXS and nuclear motion}

The short lifetime of the core-hole state causes broadening of each energy level, leading to overlap between neighboring vibrational levels in the molecule, if the vibrartional spacing is of the same order of magnitude as the lifetime width. But if the bandwidth of the incoming photons are comparable or smaller than the lifetime of the core-excited state it is possible to investigate formation of resonant x-ray spectra as a function of frequency detuning. Consider the detuning energy $\Omega$ defined as the difference between the excitation photon energy $\Omega$ and the center of the core excited state with lifetime width $\Gamma$ we get

$$
T=\frac{1}{\sqrt{\Omega^{2}+\Gamma^{2}}}
$$

which characterize the duration time or 'suddenness' $\mathrm{T}$ of the resonant $\mathrm{x}$-ray process (see figure 1.3). 


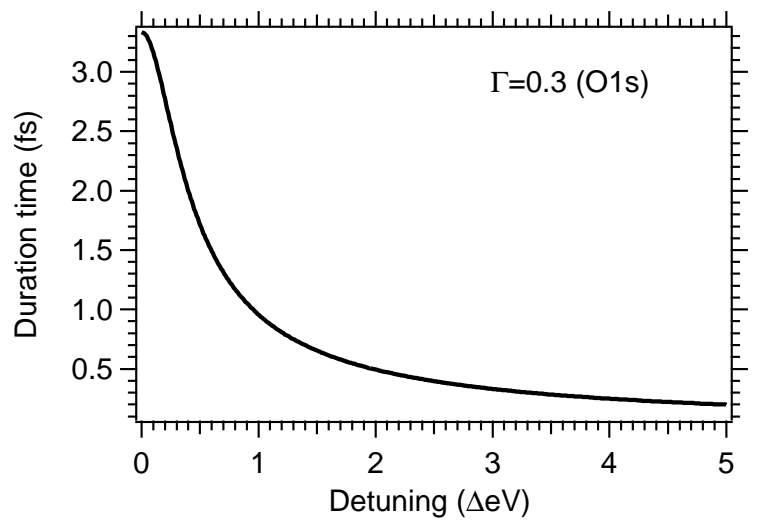

Figure 1.3: The duration time $(\mathrm{T})$ of the resonant $\mathrm{x}$-ray process as a function of detuning energy $(\Omega$, using lifetime width $(\Gamma)$ of $0.3 \mathrm{eV}$ for O1s.

The core-hole lifetime is fixed property of the atom, but the incoming frequency can be freely chosen. As seen in figure 1.3 for zero detuning (on resonance) the duration time is govern by the core-hole lifetime (here $3.3 \mathrm{fs}$ ), and already at $1 \mathrm{eV}$ detuning scattering time is shortened, below $1 \mathrm{fs}$. 


\section{Chapter 2}

\section{Experimental}

\subsection{Synchrotron radiation}

Synchrotron radiation was used as excitation source for the experiments. A synchrotron source basically consists of a storage ring were electrons travel at $\mathrm{GeV}$ energies, i.e. near the speed of light. The electron beam is maintained in the storage ring by strong magnetic fields. The storage ring is not actually circular, but it is constructed of a set of straight sections connected by strong magnets which bend the electron beam. When an electron experiences acceleration motion it emits light and lose some its energy. The energy loss of the electron beam is compensated by oscillating radio frequency cavities in the ring. There are three types of magnetic structures commonly used to produce the radiation: dipole 'bending' magnet, undulator, and wiggler. A dipole magnet produce a narrow fan of radiation of continuous wavelength around the center of the dipole.

Undulators are periodic magnetic structures with relatively week magnetic fields. The periodicity causes the electron to experience a harmonic oscillation. The undulator produce an extremely small radiation cone with very small angular divergence and special width. Wigglers use higher magnetic fields than undulators producing higher radiation power but with a broader radiation cone in space and angle. The radiation is dominated by a large number of harmonics that merge to a continuum at high energy, similar to shape of bending magnet radiation but shifted to higher energy and increased photon flux. In the Soft x-ray range undulators are preferably used, which are installed in straight sections in the storage ring. In most common configurations the undulator deliver linear polarized light with the polarization direction in the plane of the storage-ring. The radiation is greatly reduced in wavelength $\lambda$ from that of the magnet period $\lambda_{u}$, by Lorentz contraction and relativistic Doppler shift as determined by the extended undulator equation [1]

$$
\lambda_{n}=\frac{\lambda_{u}}{2 n \gamma^{2}}\left(1+\frac{K^{2}}{2}+\gamma^{2} \theta^{2}\right),
$$

which describes the generation of short wavelengths through the factor $\frac{\lambda_{u}}{2 \gamma^{2}}$, 


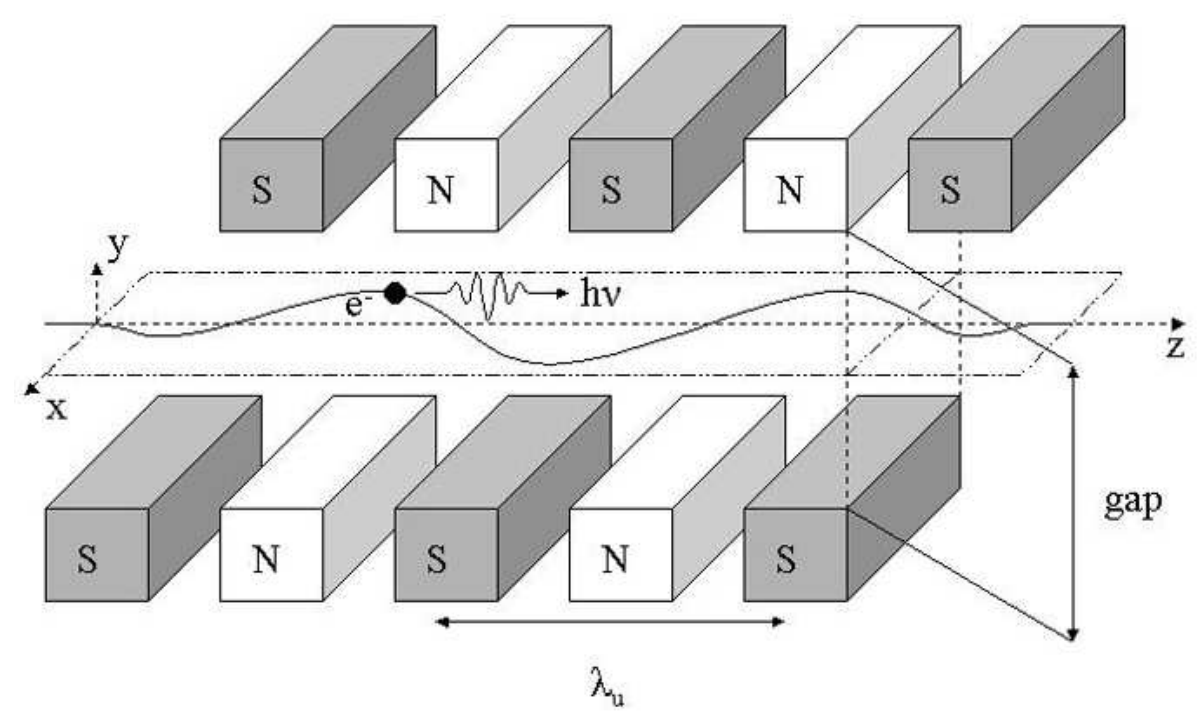

Figure 2.1: Schematic picture of an undulator or a wiggler.

magnetic tuning $\frac{K^{2}}{2}$, and off-axis wavelength variations through $\gamma^{2} \theta^{2}$. The effect of transverse oscillations introduce higher harmonics denoted as $n$, where the odd harmonics $(\mathrm{n}=1,3,5, .$.$) radiate on axis into a narrow forward cone. The$ wavelength is tuned through the undulator parameter $K$ given by

$$
K=\frac{e B \lambda_{u}}{2 \pi m c}
$$

where the magnetic flux density $B$ is modulated by changing the gap between the two periodic magnetic structures. The third term depends on $K$, the Lorentz contraction factor $\gamma$ and the number of magnetic pairs in the undulator.

After the undulator the radiation is further monochromatized using gratings and focused to a small spot on the sample. There are different types of monochromators, usually employing spherical or plane gratings. They basically use gratings to disperse the radiation and a slit assembly to select the desired energy. The focusing is done with spherically or elliptically shaped mirrors. Elliptical mirrors are preferably used, as spherical mirrors give abberations. In the X-ray range all mirrors and gratings have to be operated at grazing incidence angles, because the reflective coefficient is very small at normal incident. Grazing incident works since $\mathrm{n}<1$. The use of a pair of spherical mirrors, placed orthogonal to each other at glacing incidence, was originally suggested by Kirkpatrick and Baez. [16] The first mirror provides focusing in the horizontal direction while the second mirror provides focusing in the vertical direction.

The high flux soft x-ray radiation at beamline 7.0.1 (The Advanced Light Source) is produced by a $5 \mathrm{~cm}$ period undulator and a spherical grating monochromator [42], and the beam is focused by two spherical mirrors for both vertical and horizontal directions. At beamline I511-3 of MAXII, the soft x-rays are produced by a $5.2 \mathrm{~cm}$ period undulator and a modified SX700 plane grating monochroma- 
tor. The beam is focused using two elliptical mirrors which produce a spot size of $20 \mu \mathrm{m}$ in the vertical direction. All experiments were performed under vacuum conditions. Vacuum is needed because the soft x-rays only penetrate a few $1000 \AA$ in atmospheric pressure. Some of the experimental equipment, such as detectors, operate under vacuum conditions. Most of the battery related samples contain lithium and are therefore not to be in contact with oxygen and nitrogen. The samples were transferred into the vacuum chamber using a load lock system. A glove bag was attached to the load lock and kept under argon flow.

\subsection{Soft X-ray Emission Spectrometer}

Soft X-ray emission spectra were recorded using a high-resolution grazing-incidence grating spectrometer [26]. The spectrometer was constructed at Uppsala University. The instrument is based on Rowland geometry, which achieves both wavelength dispersion and focusing in a single step. It consists of slit, gratings and detector. Three spherical gratings are optimized to cover an operation range from 50 to $1000 \mathrm{eV}$. X-rays of different wavelength $\lambda$ are diffracted according to the grating equation

$$
n \lambda=d(\sin \alpha-\sin \beta),
$$

where the integer $n$ stands for different orders of diffraction, the grating constant $d$ is the distance between two grooves, and $\alpha$ and $\beta$ defines the angle of incident and diffracted light, respectively. In this design the gratings are mounted at angles of incidence with a joint fixed entrance slit, i.e. the three gratings have individual and fixed incidence angle. The resolution of the grating, with grating constant $d$, is determined by the total number of illuminated grooves and the diffraction order. Zero order, $n=0$, gives no dispersion, while going to higher orders gives higher resolution. In the Rowland spectrometer, focusing of the source (the slit) is achieved if slit and the detector is placed together with a grating on a circle with a radius of half the grating radius $[29,36]$. The resolution is dependent on the opening of the entrance slit, which is adjustable and can be varied between zero and $\sim 100 \mu \mathrm{m}$. Because of spherical abberation and coma the resolution of the spectrometer is also dependent on the illumination of the grating, and for achieving the best possible resolution the grating should be illuminated with a certain illumination width. Geometrical and diffraction limitations give a limit of the wavelength resolution $\Delta \lambda$ of

$$
\Delta \lambda=1.1 \frac{\omega_{s} d}{n R},
$$

where $\omega_{s}$ is the slit-width and $R$ is the grating radius.

$\mathrm{X}$-rays are detected by a two-dimensional detector which can be positioned and oriented tangentially to the pertained Rowland circle. The detector is placed inside a housing, which is is mounted in such a way that it can be moved along two perpendicular spatial axes. The detector can also be rotated around an axis parallel to the detector surface in order to stay tangential to the Rowland circle 


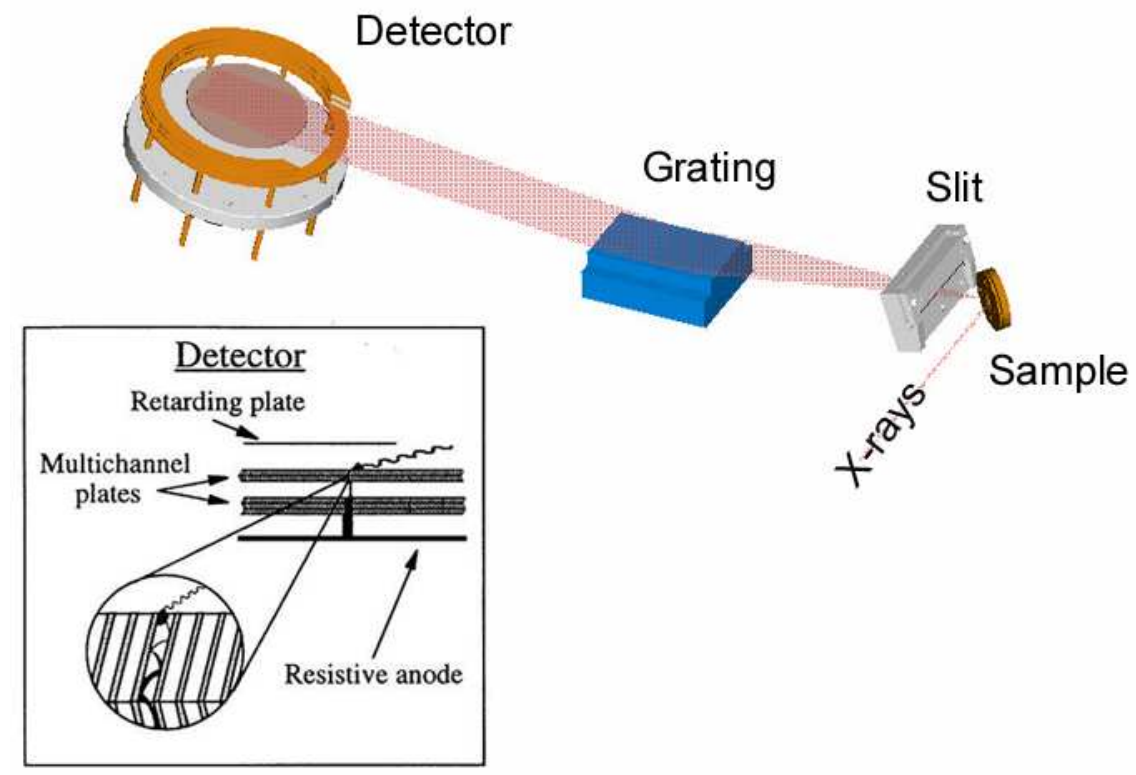

Figure 2.2: Schematic illustration of the soft x-ray spectrometer (here shown with only one grating).

for all detector positions. With this setup the detector can be moved to different positions on the Rowland circle and thereby reaching different wavelength/energy windows. The desired grating and illumination chosen with two grating selectors located between the slit and the three gratings.

The two-dimensional detector consists of multi channel plates (MCP) and a resistive anode with a four electrode readout (see Fig. 2.2). The efficiency of the detector is increased by coating the top surface of the MCP with CsI. X-rays hitting the detector will produce electrons that are multiplied through the channels of the MCPs. The whole stack of MCPs are biased to push and amplify the electron cascade down to the resistive anode, where the signal is registered and the original photon event can be determined.

The x-ray absorption measurement were made using two different setups. Total electron yield (TEY) was recorded by measuring the drain current from the sample while scanning the incident photon energy. Fluorescence yield (FY) was recorded using a channeltron biased for photon detection (in negative potential). A positively biased grid was placed in front of the detector in order to reject ion contribution to the spectra. 


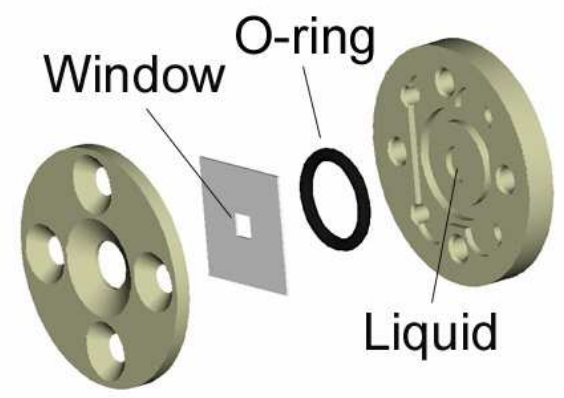

Figure 2.3: Schematic illustration of the cell used for liquid measurements. The liquid is separated from the vacuum by a $1000 \AA$ thick silicon nitride window. The in and out going $\mathrm{x}$-rays are travelling through the same window.

\subsection{The Liquid cell}

One the objectives of this thesis is to study the electronic structure of electrode materials in a electrochemical cell/battery cell. One of the difficulties is that the cell contains liquid and the soft x-ray experiments have to be under vacuum conditions. Most liquids have high vapor pressure (such as water: 10 torr at RT). Thus if a liquid is simply introduced into a high vacuum system it will instantly be vaporized and pumped out from the system before any measurements could be obtained. By a small liquid cell we are able to pursue soft x-ray spectroscopy on liquids, which is described in paper XII. The liquid is kept in a small vacuum tight container. The x-rays penetrate through a thin silicon nitride window (about 1000 $\AA$ thick), which is commercially available [38]. The outgoing photons are travelling through the same window. The transmission of x-rays at the $\mathrm{O} K$-edge for a 1000 $\AA$ thick window is about $70 \%$. This very thin membrane of $2.25 \times 2.25 \mathrm{~mm}^{2}$ can withstand a pressure difference of one atmosphere. Our cell consists of a two piece metal or plastic container, which is sealed using a standard o-ring placed between the back of the cell and the window (see figure 2.3). Ones the cell is properly sealed, it can be placed on any of our standard sample-holders and brought into vacuum system via the loadlock setup. Normal pump-down/transfer time is about $20 \mathrm{~min}$. The amount of liquid kept in this cell is about $4 \mu \mathrm{l}$. Because of safety issues, incase the window breaks, the amount of liquid inside the cell has to be minimized. Other precautions are also taken as pinholes between the experimental chamber and the beamline, and fast interlock systems for protection of the highvoltage-biased detectors.

This cell was used to study the electronic structure of various liquids, later discussed in section 3.2. A similar cell is planned to be applied to studies of

electrochemical processes in situ. In making of such a cell one of the electrodes has to be placed between the silicon nitride and the liquid/electrolyte as a thin film. 
The other electrode can be placed anywhere in the cell as long as it is in contact with the electrolyte and not with the first electrode. Preliminary experiments demonstrating the feasibility of such in situ experiments have been done.

\subsection{Sample preparations of Battery electrodes}

The measurements, on battery materials, presented in this thesis were not done using an in situ cell, but all electrochemical insertion of lithium was done outside vacuum, both for anode and cathodes materials. In the case of the anode, graphite electrodes, commonly used in Li-ion batteries, were prepared. One of the objectives was to study the changes of the electronic structure upon lithiation of graphite, i.e. the electronic structure of $\mathrm{LiC}_{6}$. Another objective was to study the chemical composition of the SEI formed on graphite electrode. in terms of chemical composition. Four graphite electrodes were prepared, one reference, two cycled in the battery cell with different composition of electrolyte, and one with possibly thicker SEI. In the case of the cathode, we were interested in the two nanostructured TM-oxides anatase $\mathrm{TiO}_{2}$ (paper III) and vanadium oxide nanotubes (paper IV).

\subsubsection{Graphite and $\mathrm{LiC}_{6}$}

A large $(10 \times 10 \mathrm{~mm})$ highly oriented pyrolytic graphite (HOPG) sample, was cleaved using adhesive tape to obtain a fresh surface prior to loading it into the vacuum chamber. The $\mathrm{LiC}_{6}$ sample was prepared, by exposing $\mathrm{HOPG}$ to $\mathrm{Li}$ vapor in a vacuum chamber. The sample was brought to the experimental chamber in a sealed container, and introduced into the vacuum system via a load lock with a glove bag under argon atmosphere. The sample was cleaved right before being loaded into the vacuum chamber, and transferred into the experiment chamber, in which the base pressure was $<1 \cdot 10^{-9}$ torr within $20 \mathrm{~min}$. The $\mathrm{LiC}_{6}$ sample had its characteristic golden color throughout the experiment time $(\sim 12 \mathrm{~h})$.

\subsubsection{Graphite electrodes/SEI}

The samples were prepared at the Department of Materials Chemistry located in Ångström laboratory. All electrochemical cells were prepared in an argon-filled glovebox and precycled. All samples were brought to the beamline (ALS) in sealed aluminum bags. A more detailed description of the sample preparation can be found in paper I.

\subsubsection{Anatase $\mathrm{Li}_{x} \mathrm{TiO}_{2}$}

Here the electrochemical insertion was done at the beamline (ALS) prior to the measurements. The electrode was prepared from a suspension of colloidal $\mathrm{TiO}_{2}$ [28]. The electrochemical ion insertion was made in a three-electrode setup, with the titanium dioxide electrode as the working electrode. The electrode/sample was after insertion brought up from the solution and transferred into the vacuum 
system via a loadlock system. The process was performed under argon atmosphere in a glove bag attached to the loadlock, so that the electrode was not in contact with air, and transferred into the experimental chamber within 20 minutes.

\subsubsection{Vanadium nanotubes}

The vanadium oxide nanotubes were prepared as described by Krumeich et al $[18,40]$ at the Department of Materials Chemistry (Ångström laboratory). A series of cycled electrodes were prepared to be discharged to different potentials $(3.0 \mathrm{~V}, 2.5 \mathrm{~V}, 2.0 \mathrm{~V}$ and $1.8 \mathrm{~V})$ to achieve different doping levels/lithium content. All samples were brought to the beamline (MAXLAB) in sealed aluminum bags. A more detailed description of the sample preparation can be found in paper IV. 


\section{Chapter 3}

\section{Results}

\subsection{Rechargeable lithium batteries}

\subsubsection{The Anode: Graphite electrodes}

Graphite materials are commonly used as anode material. During charging of the cell, lithium ions are intercalated into the graphite structure and staged $\mathrm{LiC}_{\mathrm{x}}$ phases are formed. The maximum degree of intercalation reached for $\mathrm{LiC}_{6}$, which corresponds to a theoretical capacity of $372 \mathrm{mAh} / \mathrm{g}$ (charge-storage ability). During the first intercalation of lithium ions, electrolyte compounds are reduced on the graphite surface and a Solid Electrode Interphase (SEI) is formed [30]. RIXS spectra of graphite in three different phases were measured. In section 3.1 .2 a comparison of the polycrystalline graphite electrode with highly oriented pyrolytic graphite (HOPG) is presented. In section 3.1.3 the results from the study of fully lithium intercalated $\mathrm{HOPG}\left(\mathrm{LiC}_{6}\right)$ are discussed. The results from graphite electrodes cycled in a battery, i.e. the formation of the SEI layer, are discussed in section 3.1.4.

\subsubsection{Graphite}

Figure 3.1 shows the x-ray absorption spectra of HOPG graphite and the graphite electrode, recorded at 45 degrees incidence angle. The spectra shown here are recorded in total electron yield (TEY) mode. The feature around $285 \mathrm{eV}$ is attributed to transitions from $\mathrm{C}$ 1s to unoccupied $\pi$ states. The sharp feature at $291.6 \mathrm{eV}$ is attributed to transitions from $\mathrm{C} 1$ s to a $\sigma$-state. The absorption features in the XAS spectrum of the graphite electrode resemble those of the HOPG. The $\pi$ feature $(285 \mathrm{eV})$ is broader in the graphite electrode and some intensity differences of the $\pi$ and the $\sigma$ features are seen, due to the orientation of the small graphite crystallites in the electrode. Additional intensity comes from other carbons forms in the electrode, i.e. carbon-black and carbon-binder. Approximately $20 \%$ of all carbons in the electrode are represented by carbons in carbon-black and carbons-binder, and can be described as amorphous carbon.

Figure 3.2 shows the resonantly excited emission spectra of HOPG and the 


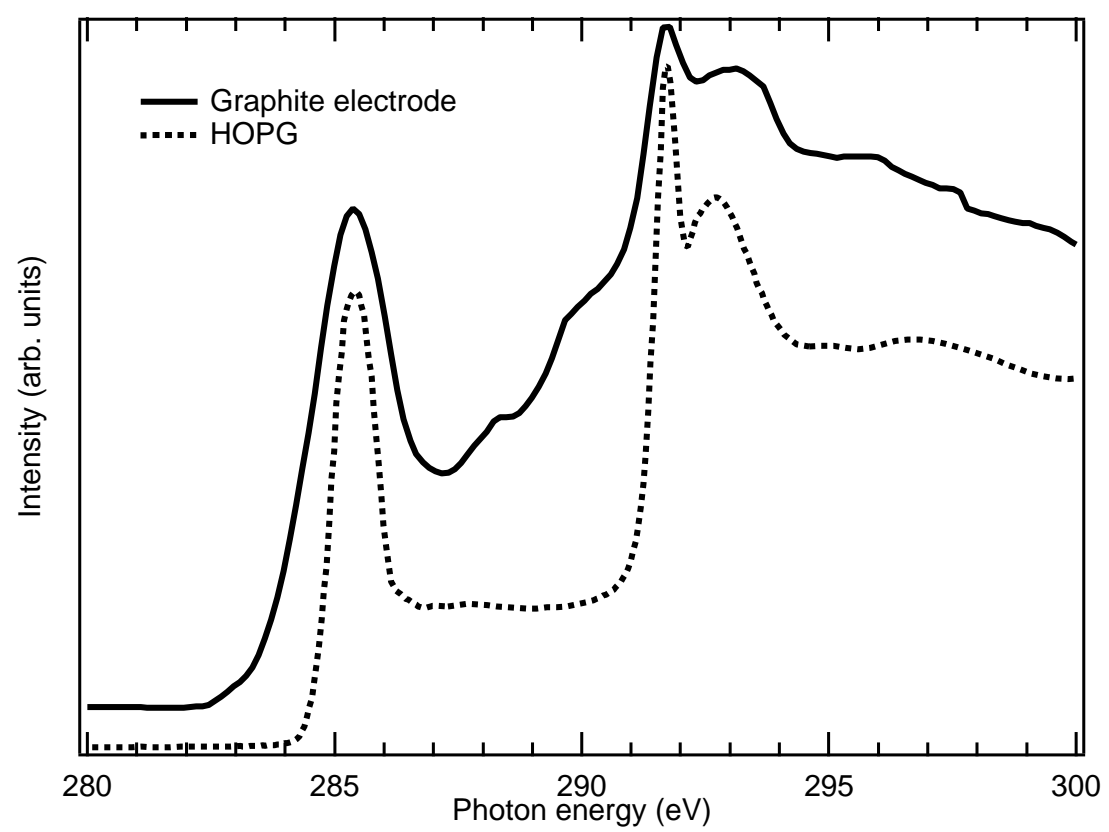

Figure 3.1: C 1s absorption spectra (TEY) of a graphite electrode and HOPG.

electrode. The sharp feature at high energy in all spectra is the elastic peak i.e. the energy of the incoming photon. The structure below the elastic peak is emission from the valence band of graphite. As the excitation energy is varied changes in the emission spectrum are seen and interpreted by considering momentum conservation (as described in section 1).

The emission spectra are recorded at $\sim 45$ degrees, which gives emission from both symmetries, with $\sigma$ and $\pi$ at $265-276 \mathrm{eV}$ and $276-285 \mathrm{eV}$ respectively. The peak below the elastic peak, in the spectrum excited at $285 \mathrm{eV}$, is emission from the $\pi$-band near the K-point in $k$-space. Accordingly, the sharp feature (same spectrum) at $272.5 \mathrm{eV}$ are transitions from the $\sigma$-band near the K-point. The next excitation energy $(288.5 \mathrm{eV})$, gives a strong $\sigma$-band at $276 \mathrm{eV}$ near the Mpoint in $k$-space $[3,4]$.

The non-resonant spectra of both systems are similar. Minor differences are found around $277 \mathrm{eV}$. On the low energy side, the graphite electrode shows a structure-less slope, whereas HOPG shows some structure. Thus, we can conclude that the non-resonant emission of the graphite electrode reflects mainly graphiteDOS. Discrepancies from HOPG are observed due to size and crystal quality of the graphite crystallites in the electrode and also contributions from carbon black and carbon binder. The graphite electrode and the HOPG show nearly the same excitation energy dependence in the RIXS-spectra. 


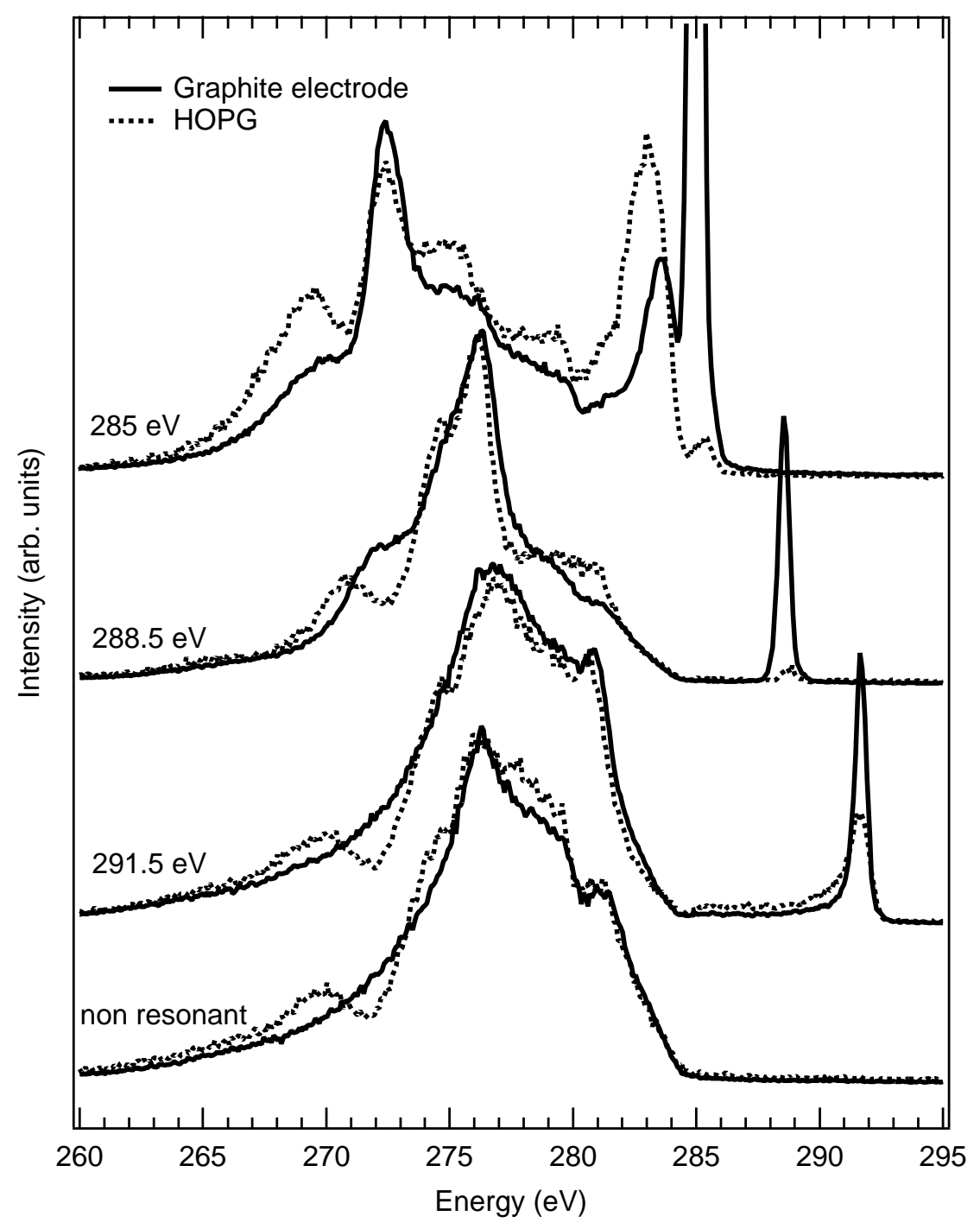

Figure 3.2: Carbon K-emission of graphite electrode and HOPG. Excitation energies are indicated.

\subsection{3 $\mathrm{LiC}_{6}$}

It is believed that, upon lithiation, the shape of the graphite density-of-states (DOS) remains largely unchanged and electrons are completely transferred from the Li 2 s states to empty carbon $\pi^{*}$ states. This can be understood within the framework of the so-called rigid-band model, where the in-plane part of the $\mathrm{LiC}_{6}$ band structure is the result of backfolding of the $2 \mathrm{D}$ bands of graphite into the smaller Brillouin zone of $\mathrm{LiC}_{6}$. However, due to the existence of lithium ions 
and the altered stacking of the graphene layers, the electronic structure needs consideration of changes in the band structure beyond the rigid-band model. The main results in paper II confirm what have been shown earlier by various other experimental results $[6,7,37]$, that electrons are transferred into empty $\pi^{*}$ states in a near rigid way.

In figure 3.3 the XAS and XES of $\mathrm{LiC}_{6}$ are presented. The spectra of HOPG are included for reference. The X-ray absorption spectra reflect the unoccupied states of $\mathrm{LiC}_{6}$. Comparing $\mathrm{LiC}_{6}$ and $\mathrm{HOPG}$, the $\sigma^{*}$ feature has shifted down $\sim 1.3$ $\mathrm{eV}$ upon lithiation (figure 3.3 upper panel). Higher DOS at $E_{F}$ implies better screening of the core hole, compared to graphite, which makes the final state shift towards lower energy in the absorption process.

Now considering the XES, the spectra are compared with the spectra of HOPG. At off-resonance (see upper panel in figure 3.3) the spectra reflect the occupied partial DOS (p-type DOS) in the material $[22,39]$. The peak around $284 \mathrm{eV}\left(\mathrm{LiC}_{6}\right)$ indicates the increased DOS at the $E_{F}$. Apart from the emission spectra showed here angle-resolved spectra were recorded to determine the $\pi$ or $\sigma$ character of the emission features. From those measurements (see paper II) it was found that the peak at the $E_{F}$ has the same $\pi$ character as the broad feature around $280.4 \mathrm{eV}$. A $\pi$ signal centered at $274.8 \mathrm{eV}$ was also found, whereas the structure around $277 \mathrm{eV}$ and $270.5 \mathrm{eV}$ has $\sigma$ character. According to the rigid-band model, there should be high DOS at $1.3 \mathrm{eV}$ below the $E_{F}$. Here we find the peak at $0.5 \mathrm{eV}$ below the $E_{F}$. This non-rigid-band shift is probably due to substantial hybridization between $\mathrm{Li}$ 2s states and carbon states.

The excitation dependence of the emission spectra is different for $\mathrm{LiC}_{6}$ compared to HOPG (see figure 3.3 lower panel). Some excitation-energy dependence is observed, but not of the dispersive nature like in the HOPG. Upon lithiation the crystal structure changes moderately but it is still crystalline i.e. the insertion of lithium does not disturb the long range crystallographic order in the system. It is possible that it is the increased DOS at $E_{F}$ which affects the coherence in the scattering process. For example resonant emission spectra of metals do not show momentum conservation. This is believed to be due to the final state being delocalized and the coherence is lost due to electron-electron interactions in the intermediate state.

\subsubsection{The formation of the SEI layer}

During discharge of the battery the lithium ions are pulled out from the anode (deintercalation). Now we will consider the graphite anode after the first cycle i.e. lithium ions have been inserted and extracted again one time. In theory, $\mathrm{Li}^{+}$intercalation into the graphite is fully reversible, however, the charge consumed in the first cycle exceeds the theoretical specific charge for the first stage of $\mathrm{LiC}_{6}$ of $372 \mathrm{Ah} / \mathrm{kg}$. The subsequent deintercalation of $\mathrm{Li}^{+}$recovers about 80$90 \%$ of this charge. In the second and subsequent intercalation cycles, however, charge consumption for $\mathrm{Li}^{+}$intercalation is lowered and charge recovery is close to $100 \%$. The charge consumption in the first cycle is generally ascribed to for-

mation of a solid electrolyte interface (SEI) layer and corrosion-like reactions of $\mathrm{Li}_{\mathrm{x}} \mathrm{C}_{6}$. As metallic lithium and lithium-rich Li alloys are thermodynamically un- 

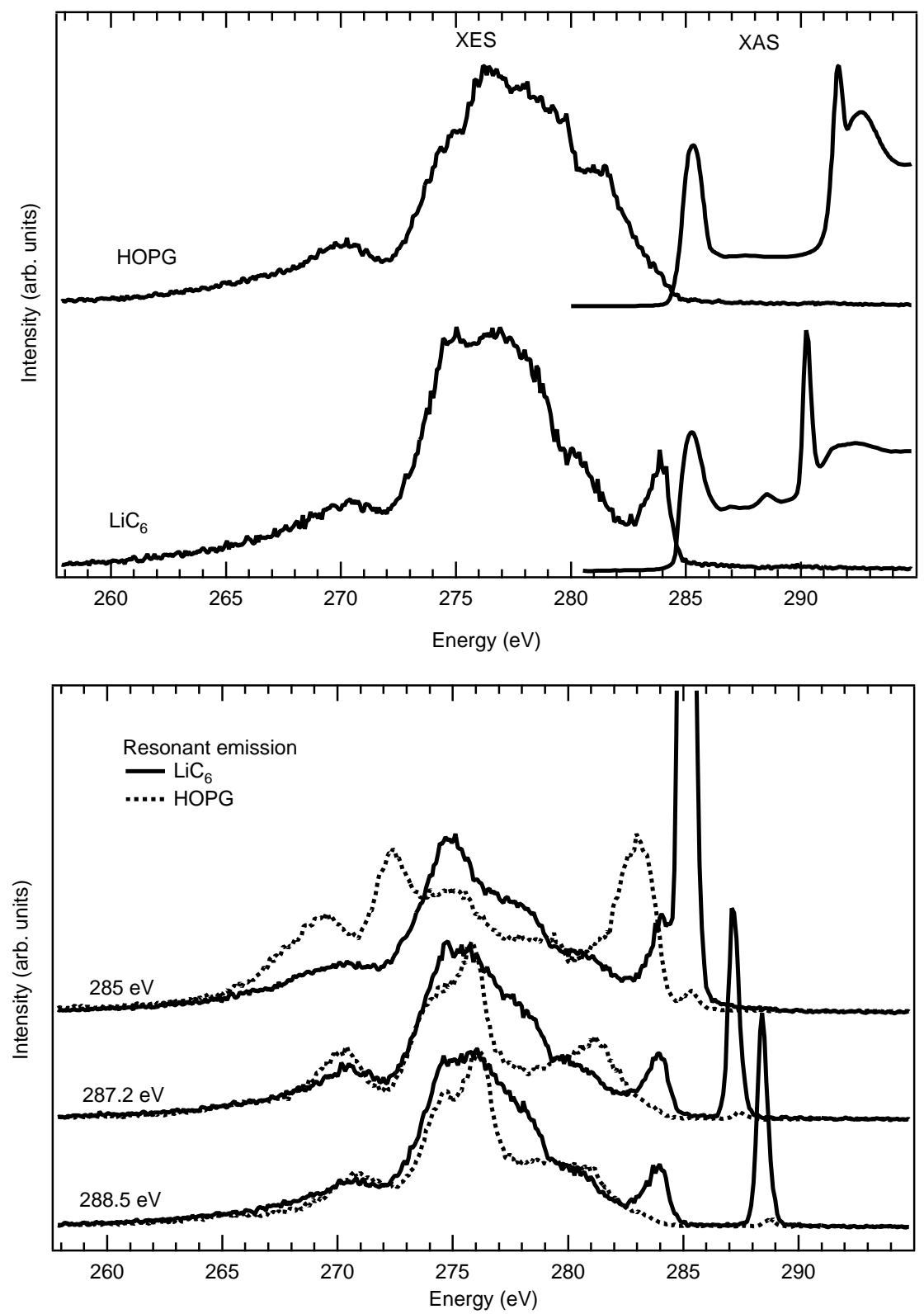

Figure 3.3: Upper panel: Normal C K-emission and C 1 s absorption spectra of $\mathrm{LiC}_{6}$ and HOPG. Lower panel:Resonant C-emission of $\mathrm{LiC}_{6}$ and $\mathrm{HOPG}$, where excitation energies are indicated. 
stable in all known electrolytes, the surfaces which are exposed to the electrolyte, have to be protected by SEI films. The layer formation on $\mathrm{Li}_{\mathrm{x}} \mathrm{C}_{6}$ surfaces takes place as a charge-consuming side reaction in the first of a few cycles of $\mathrm{Li}^{+}$intercalation/deintercalation. The charge loss frequently called "irreversible specific charge" is strongly affected by: a) the crystallility and the morphology of the parent carbonaceous material and b) the chemical composition of the electrolyte. It is generally accepted that the intercalation of $\mathrm{Li}^{+}$from organic donor solvent electrolytes into fairly crystalline graphitic carbons quite often leads to solvated graphite intercalation compounds, $\operatorname{Li}(\operatorname{solv})_{\mathrm{y}} \mathrm{C}_{\mathrm{n}}$. The so-called "solvated intercalation" is associated with extreme expansion of the graphite matrix $(\sim 150 \%)$, that often leads to deterioration of the graphite and as a result to a drastically decreased charge storage capability. Solvated intercalation of lithium into carbon electrodes is a serious problem, particularly in the first few cycles before the protecting film on the $\mathrm{Li}_{\mathrm{x}} \mathrm{C}_{6}$ is finished, where the tendency of solvent co-intercalation is high. Ethylene carbonates (EC) have been used to prevent the formation of $\operatorname{Li}(\mathrm{solv})_{\mathrm{y}} \mathrm{C}_{6}$, because the decomposition compounds of EC form an effective protective film on the graphite surface in the early stage of the first reduction. The film prevents excessive solvent co-intercalation. Mixtures of EC with other solvents as $\mathrm{DMC}^{1}$, $\mathrm{DME}^{2}$ and $\mathrm{DEC}^{3}$ are preferred because of the low viscosity of EC. The reduction of the host material is not just a simple surface reaction but a rather complex threedimensional process. The reactions can take place on internal surfaces between the graphene layers. Numerous research activities have focused on the improvement of the protective films and the suppression of solvent co-intercalation, either by choice of electrolyte or by pre-coordinating of the carbon electrode.

The graphite electrode was used as anode material in a battery and cycled (discharged and charged). X-ray absorption spectra of three cycled electrodes, presented in paper I, show a sharp feature at $290.3 \mathrm{eV}$. Note, that's nearly the same energy as the $\sigma^{*}$ in $\mathrm{LiC}_{6}$, but it's attributed differently here, which is clear from the x-ray emission spectra. This feature is now attributed to species in the SEI layer.

Let us compare the emission spectra of the three electrodes. The same excitation energies were used to record the emission spectra (figure 3.4.) of the three cycled electrodes (spectra of a graphite electrode are added for comparison). Even though there are spectral differences comparing the electrodes, it is obvious that the "finger-prints" of graphite is seen in all electrodes. There is no intensity at $E_{F}$ as in $\mathrm{LiC}_{6}$ (except for the spectrum excited at $285 \mathrm{eV}$, which are transitions from the $\pi$-band near the K-point of graphite).

The graphite recovered form $\mathrm{LiC}_{6}$ and the rule of momentum conservation in the scattering process is valid. Spectral differences are observed in the spectra excited at the first three energies $(285,288.6$, and $290.3 \mathrm{eV})$. Even the non-resonantly excited spectra show small differences around $279 \mathrm{eV}$ comparing the electrodes.

This is attributed to emission from carbons in the SEI layer. The spectra of the electrodes were compared with spectra of reference compounds, sodium succinate, lithium carbonate, lithium oxalate, lithium methoxide and pure ethylene carbonate

\footnotetext{
${ }^{1}$ Dimethyl carbonate

${ }^{2}$ Dimethoxyl ethane

${ }^{3}$ Diethyl carbonate
} 


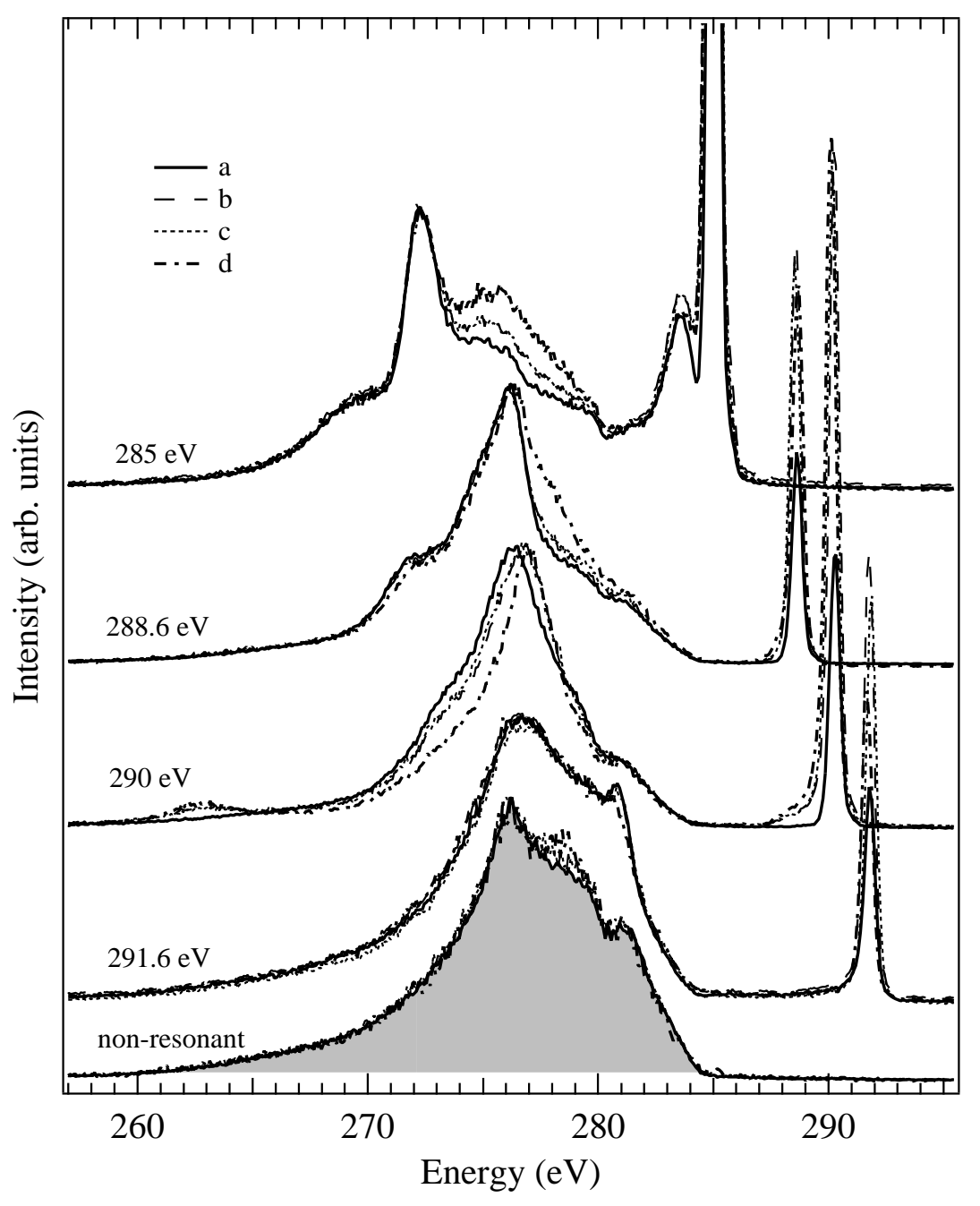

Figure 3.4: Resonant C K-emission spectra of graphite electrodes , (a) uncycled, (b) cycled with EC:DMC, (c) cycled with PC:EC and (d) cycled with EC:DMC and spontaneously deintercalated.

(EC). Before comparison the graphite intensity were subtracted. In figure 3.5. the spectra of graphite was subtracted from the spectra of the electrode with thick SEI (d). The subtraction was made in such a manner that no negative intensity was found in the resulting spectrum. The obtained spectra of the SEI species was compared with spectra of the reference compounds, recorded using the same excitation energies as used for graphite electrodes. The best fit was obtained using a combination of emission intensities of sodium succinate, lithium oxalate and lithium methoxide. 


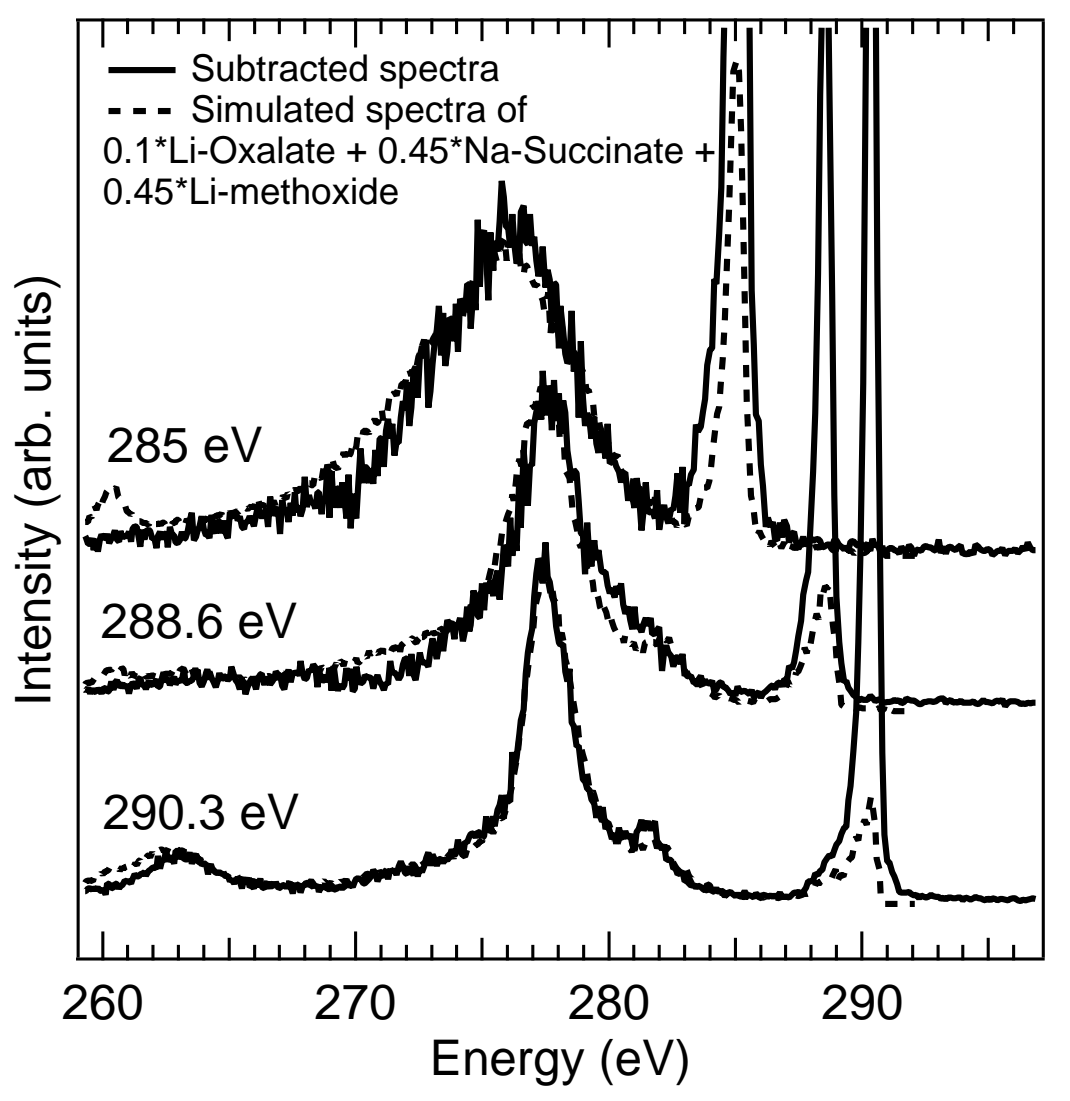

Figure 3.5: The difference spectra of electrode (d) and graphite, compared with spectra composed of Na-succinate, Li-oxalate, and Li-methoxide.

\subsubsection{Summary Graphite Anodes}

Resonant soft-x-ray emission spectra of pristine graphite electrode show similar excitation energy dependence as HOPG, and can be understood in terms of symmetry resolved band structure. When lithium is intercalated into graphite $\left(\mathrm{LiC}_{6}\right)$ the XES spectra reveal increased density of states at $E_{F}$. Some excitation energy dependence of the XES spectra are observed, but can not be explained by band dispersion. Comparison with theory showed that the lower lying states were in good agreement with XES data, but the $\pi$ states closest to $E_{F}$ were found closer the $E_{F}$ than what has been predicted by theory. The formation of the SEI was investigated in cycled graphite electrodes. Content of oxygen and fluorine was found by x-ray absorption. Additional features were found in the $\mathrm{C} 1 \mathrm{~s}$ absorption spectra of the cycled electrodes. By tuning the excitation energy to these features, in the XAS spectrum, x-ray emission from SEI species were enhanced. Comparison with resonant $\mathrm{x}$-ray emission spectra of model compounds suggests that the SEI 
on the graphite electrodes consists of lithium oxalate $\left(\mathrm{Li}_{2} \mathrm{C}_{2} \mathrm{O}_{2}\right)$, lithium succinate $\left(\mathrm{LiO}_{2} \mathrm{CCH}_{2} \mathrm{CH}_{2} \mathrm{CO}_{2} \mathrm{Li}\right)$ and lithium methoxide $\left(\mathrm{LiOCH}_{3}\right)$.

\subsubsection{The Cathode: Transition Metal Oxides}

Transition metal oxides have tended to be the most attractive candidate as active cathode material in rechargeable lithium batteries. Most commercial batteries are based on cobalt, nickel and manganese oxides, but there is still a search for new materials which have higher power capacity, are cheaper, safer and less toxic. In these papers we have studied a few new prospect materials, mainly focusing on the effect on the electronic structure upon lithium insertion/extraction into the transition-metal based cathode.

\subsubsection{Nanoporous Anatase $\mathrm{TiO}_{2}$}

The performance of a rechargeable Li-battery can be improved by incorporating nanomaterials in electrodes or electrolyte $[15,31,43]$. The interest in nanostructured $\mathrm{TiO}_{2}$ is based on the possibilities of using the material in various applications as batteries [11], displays [10] and dye sensitized solar cells [28].The electrode consists of interconnected nanocrystallites forming a nanoporous structure with an extremely large inner surface allowing for electrochemical reactions to take place in almost the entire volume of the electrode. High charging capacities are reported $[10,11]$, when lithium is inserted into the nanoporous anatase titanium dioxide electrode. Schematically the electrochemical insertion reaction is written as $\mathrm{xLi}^{+}+\mathrm{TiO}_{2}+\mathrm{xe}^{-} \rightleftharpoons \mathrm{Li}_{\mathrm{x}} \mathrm{TiO}_{2}$ where $\mathrm{x}$ is the mole fraction of lithium in the titanium dioxide.

Figure 3.6 shows resonant emission spectra of Anatase $\mathrm{TiO}_{2}$ as a function of lithium concentration. The spectra are plotted on a final state energy scale, obtained by subtracting the excitation energy from the emission energy. Titanium dioxide $\left(\mathrm{Li}_{\mathrm{x}} \mathrm{TiO}_{2} / \mathrm{x}=0\right)$ has formally no d-electrons $\left(d^{0}\right)$, when lithium is inserted into the compound $(x>0)$ electrons are doped into the d-states $\left(t_{2 g}\right.$-states $)$. This is seen from the XES spectra, showing intensity below the elastic peak at $-1.1 \mathrm{eV}$, which grows with increasing doping. This is attributed to $d d$-excitation within the $t_{2 g}$ band of $\mathrm{TiO}_{2}$. At this resonance/energy, the core electron is excited (from the ground state) into unoccupied $t_{2 g}$-states (intermediate state). In the final state the core hole is filled and an electron is in an excited state i.e. $t_{2 g}$-state. Energy conservation implies that, the energy of the outgoing photon $\left(E_{\text {out }}\right)$ is equal to the energy of the incoming photon $\left(E_{i n}\right)$ minus the energy of the excited state $\left(E_{\text {ex }}\right)$. Other excitations were also found in the spectra of $\mathrm{Li}_{\mathrm{x}} \mathrm{TiO}_{2}$, as $d d$-excitations from $t_{2 g}$ to $e_{g}$ (crystal field excitations) and CT-excitations. CT, implies transfer of electrons from occupied $\mathrm{O} 2 \mathrm{p}$ to unoccupied Ti $3 \mathrm{~d}$-states and were also found in the spectra of pristine $\mathrm{TiO}_{2}$.

The lithium insertion into $\mathrm{TiO}_{2}$ show many similarities to another titanium system, $\mathrm{La}_{x} \mathrm{Sr}_{1-x} \mathrm{TiO}_{3}$, which was studied and presented in paper XIV. Here, the Ti 3d occupancy is increased when $\mathrm{Sr}$ is substituted by La, changing the physical properties of these materials. $\mathrm{La}_{x} \mathrm{Sr}_{1-x} \mathrm{TiO}_{3}$ is a wide band insulator for $\mathrm{x}=0$, but for only small deviations gives a metallic behavior. $\mathrm{SrTiO}_{3}$ has formally no 


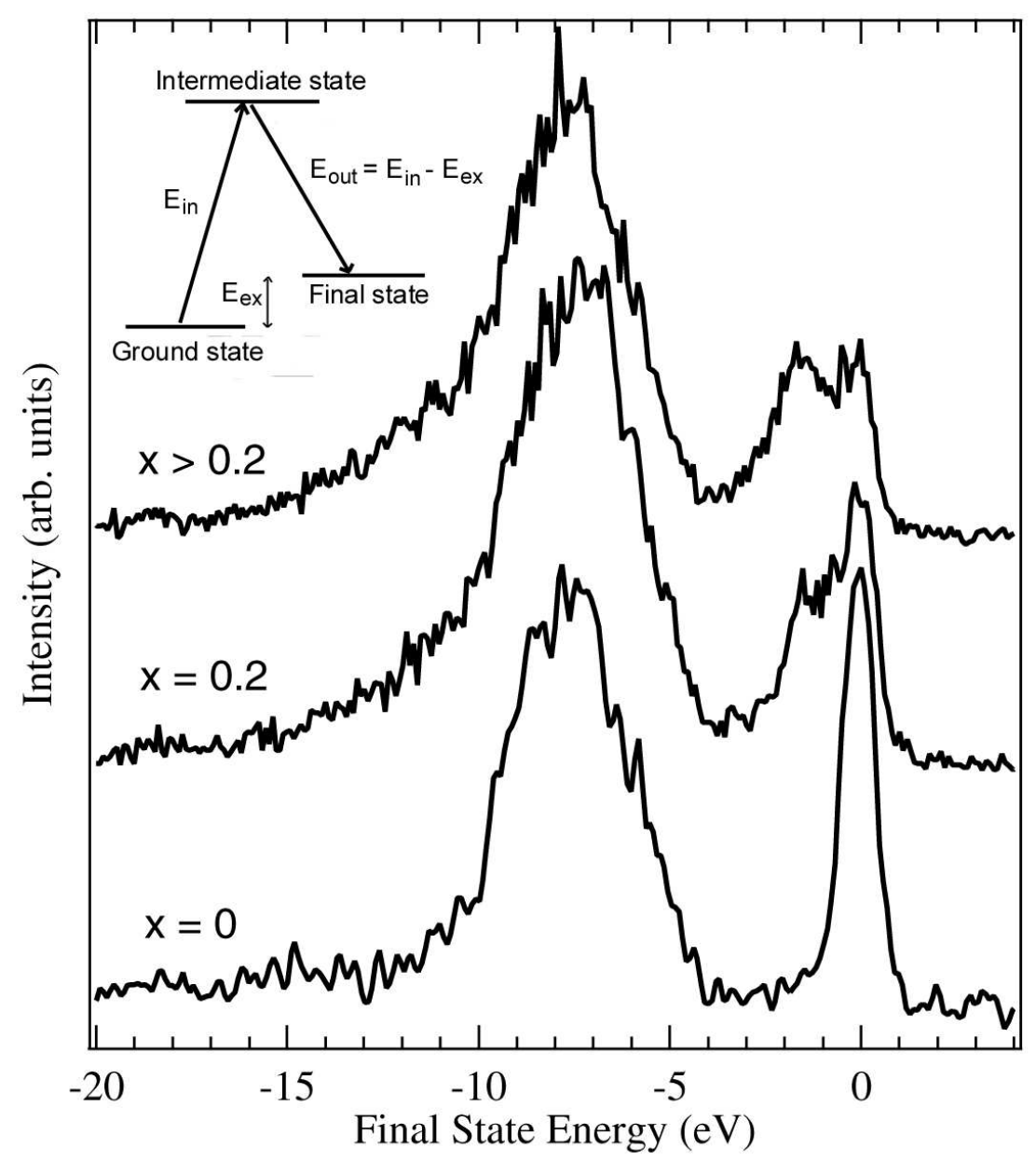

Figure 3.6: RIXS spectra of lithium ion inserted nanoporous $\mathrm{TiO}_{2}$ at the $t_{2 g^{-}}$ resonance. The schematic picture illustrates the RIXS process, were $E_{\text {in }}$ and $E_{\text {out }}$ are the energy of the incoming and outgoing photon, respectively. The energy of the excited state $\left(E_{e x}\right)$, is in this case an excitation within the $t_{2 g}$-band (d-d excitation).

Ti d occupancy, same as $\mathrm{TiO}_{2}$, and valence band ultraviolet photoemission spectra are well-described within a one-electron picture as mapping the one-electron DOS, all together suggesting that correlation is less important. For $\mathrm{x} \neq 0$ two new features in the band gap appear, one close to the Fermi level which can be interpreted as a direct consequence of doping into a rigid one-electron band, the second feature cannot be described within the band-picture, but is in agreement with the predictions of the Mott-Hubbard model.

In contrary to $\mathrm{Li}_{x} \mathrm{TiO}_{2}$, excitations on the resonances, which are primarily associated with $4+$ vacancy gives energy-losses associated with $3+$ sites. If we make the assumption that the electron hopping rate is much larger than the char- 
acteristic life-time of the intermediate state, no selectivity in the first absorption absorption step of the scattering process is made, but the second emission step would reflect the average occupancy of the $\mathrm{Ti} \mathrm{d}$ band, which we can assume is proportional to $\mathrm{x}$. Then, the resonantly excited emission spectrum (for $\mathrm{x} \neq 0$ ) can be described as linear combinations of the $\mathrm{SrTiO}_{3}$ spectrum, and the spectrum associated with the additional Ti $d$ electron (see paper XIV). These results can be directly compared to calculations of the partial DOS of trivalent $\mathrm{LaTiO}_{3}$, with the LDA+DMFT(QMC) method [24]. In this calculation the Coulomb interaction between $t_{2 g}$ electrons are taken into account, which simulates a classical Hubbard picture. The final states observed in the RIXS spectra were identified as transitions from the "lower Hubbard band" to the "quasi-particle band", and crystal field excitations $\left(t_{2 g} \rightarrow e_{g}\right)$. The results support a linear superposition model which describes the doped material as a mixture of $\mathrm{Ti}^{4+}$ and $\mathrm{Ti}^{3+}$ sites.

\subsubsection{Vanadium Oxide Nanotubes}

The nanotubes consist of layers of vanadium oxide separated by structure directing molecules, also called templates. These molecules can be readily exchanged for metal ions, e.g. alkali, alkaline earth or transition metal ions [32]. The layers are arranged in a scroll-like manner with open ends. The lengths and diameters depend on the choice of template $[18,32]$. The tubes consist of 2-30 layers of vanadium oxide, and are up to $15 \mu \mathrm{m}$ long with outer diameters of $15-100 \mathrm{~nm}$. The tubeopenings range from $5-50 \mathrm{~nm}$. This new material has recently demonstrated to be a well-functioning electrode material for rechargeable Li-batteries [5, 27].

Lithium insertion in vanadium oxide nanotubes were studied using RIXS. A series of cycled electrodes were prepared, which were discharged to different potentials resulting in different content of lithium. The cells were cycled one time. After that, they were slowly discharged to a preset potential $(3.0 \mathrm{~V}, 2.5 \mathrm{~V}, 2.0 \mathrm{~V}$ or $1.8 \mathrm{~V}$ ) and equilibrated. The cells were disassembled in the glove box and the electrodes were washed by DMC to remove excess electrolyte salt. Figure 3.7 show absorption and and emission spectra of the electrodes. As in the study of $\mathrm{TiO}_{2}$ (see section 3.1.7 and paper III) the spectra reflect 3d unoccupied and occupied states. The gradual changes in the spectra are attributed to electron transfer into unoccupied V 3d states as Li-ions are inserted into the material. The emission spectra consist of three distinct components: normal emission at fixed emission energy, elastic scattering features at the excitation photon energy and inelastic scattering features. The normal $\mathrm{V} L$-emission reflects the density of states (DOS) and consists of two features, due to the strong hybridization between $\mathrm{O} 2 \mathrm{p}$ and $\mathrm{V}$ $3 \mathrm{~d}$ states. The feature centered at $509 \mathrm{eV}$ is interpreted as $\mathrm{V} 3 \mathrm{~d}$ states strongly hybridized with $\mathrm{O} 2 \mathrm{p}$, whereas the feature centered around $515 \mathrm{eV}$ is interpreted as states of pure $\mathrm{V} 3 \mathrm{~d}$ character. We clearly observe that the ratio of these two features changes as the lithiation increases. The sharp peak at $520.5 \mathrm{eV}$ is the elastic peak and at $1 \mathrm{eV}$ below there is a sign of an inelastic peak attributed to $d d$-excitation within the $t_{2 g}$ band. Both XAS and RIXS measurements, from the results in paper IV, point to a partial reduction to $V^{3+}$ at potentials below $2.0 \mathrm{~V}$. The excitation energy dependence of the XE spectra points to a charge separation in the material of coexisting $d^{2}, d^{1}$ and $d^{0}$ at high doping levels. The existence of 

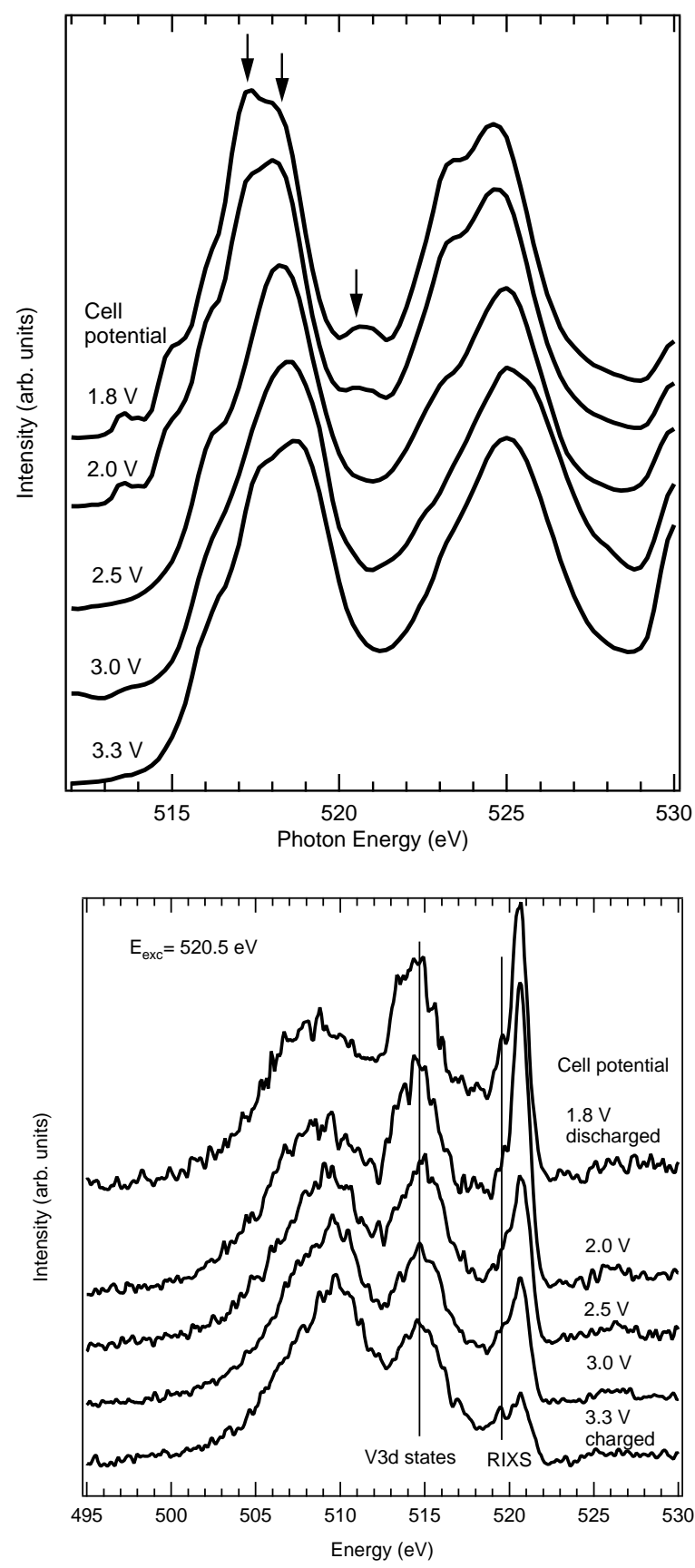

Figure 3.7: Top panel, V 2p absorption spectra and bottom panel resonant V $L$ emission of lithium inserted vanadium oxide nanotubes. The emission spectra are excited at $520.5 \mathrm{eV}$. Changes in the spectra are observed as V 3d states are filled due to the lithium insertion. 
low energy loss features (RIXS) is pointing at some degree of localization of the V 3d-orbitals.

\subsubsection{Lithium insertion into $\mathrm{V}_{6} \mathrm{O}_{13}$ cathodes}

Electrochemically lithiated $\mathrm{Li}_{x} \mathrm{~V}_{6} \mathrm{O}_{13}(\mathrm{x}=0,1, \ldots, 6)$ has been investigated, in a study similar to that of Vanadium nanotubes. This battery cathode also exhibit a very high capacity (ca. $310 \mathrm{mAh} / \mathrm{g}$ ) and has an open crystal structure [8,23]. The crystal structure of $\mathrm{V}_{6} \mathrm{O}_{13}$ comprises distorted $\mathrm{VO}_{6}$ octrahedra with shared edges and corners, where this octrahedras form a single and a double layer, connected via shared corners [12]. In paper VI the oxidation state changes during lithiation of the cathode was studied with XAS and RXES by comparison with spectra of know reference vanadium oxide compounds. As the structures of the phases ( $\mathrm{x}$ $=0,1$, and 3) are know, DFT electronic band calculations were performed and elaborated in paper VII. The results from paper VII showed that the valence band of $\mathrm{V}_{6} \mathrm{O}_{13}$ is modified in a nearly rigid band like behavior upon lithiation. The effect of V3d-O2p hybridization changes upon lithiation could also be seen.

\subsubsection{Phospho-olivines $\mathrm{LiFePO}_{4}$}

$\mathrm{LiFePO}_{4}$ has been propoced as good candidate as a cathode material. It exhibit a higher capacity than that of $\mathrm{LiCoO}_{2}$, which is widely used commercially today, it is non-toxic and less expensive. The big problem with this material is low conductivity.

Soft x-ray spectroscopy was used to investigate the electronic structure of olivetype $\mathrm{LiFePO}_{4}$ and $\mathrm{FePO}_{4}$. Olive-type $\mathrm{FePO}_{4}$ was obtained by chemical extraction of lithium from $\mathrm{LiFePO}_{4}$ powder. Two types of theoretical calculation were conducted; local excitations within Fe d-states simulated using crystal field multiplet theory, and partial density of states calculations using density functional theory. The former, ionic picture, was used to simulate the XAS and RIXS spectra at the Fe 2p edge. The latter (first principal calculations) was used to simulate the XAS and XES at the $\mathrm{O}$ 1s edge, which gives information about hybridization effects. In $\mathrm{LiFePO}_{4}$, localized Fe d-states are found around the Fermi level only slightly hybridized with oxygen p-states. Hybridization is also found among lithium sand p-states, oxygen p- and phosphorus p-states. When lithium is extracted oxygen p-states shifts towards the Fermi level leading to strong bonding between Fe d-states and oxygen p-states leading to delocalisation of the iron states.

\subsection{Liquids}

By the use of synchrotron radiation and soft x-ray emission spectroscopy it is possible to obtain new information of both geometric and electronic structure of molecules in the liquid phase. Intermolecular interactions influence the electronic structure of the molecules. Synchrotron radiation based x-ray diffraction and neutron diffraction techniques are traditionally used to determine the molecular geometry of liquids, but the electronic structure has hitherto been less addressed 


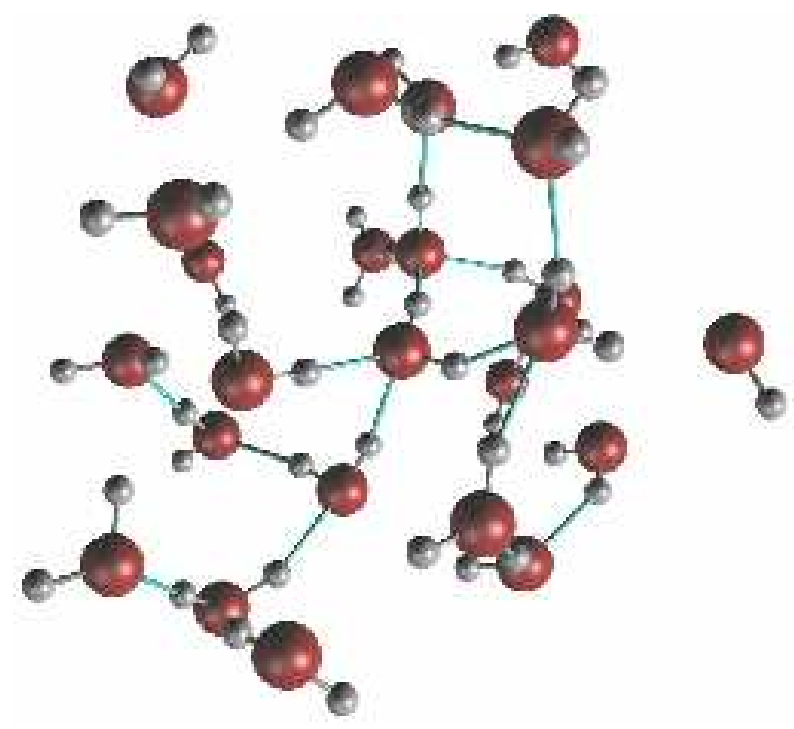

Figure 3.8: Structure of liquid water from molecular dynamics simulation.

manly due to previous technical problems of handling samples in vacuum conditions. By the use of very thin and strong x-ray windows it is now possible to separate the liquid from the vacuum in the experimental chamber, described in section 2.3. Lately a number of studies on liquid/wet samples have been reported manly using soft x-ray absorption spectroscopy as, liquid water $[9,14,34]$, ions in solution [19] and the surface structure of liquid water [13]. XAS has also show to be sensitive to geometric and electronic structure but is limited to only give information about the unoccupied states, and the measured spectrum is, as normal x-ray emission, a sum of all microscopic structures. By the use of resonant x-ray emission specific microscopic structures in the liquid can be selected and separated. The complexity of liquid systems makes it impossible to interpret the spectra with physical intuition only and theoretical simulations are essential for the understanding of the spectra. A cluster model which contains a few solvation shells around around the absorbing molecule has successfully been used to simulate and describe both absorption and emission spectra. For resonant and non resonant x-ray emission spectra a simple semi-continuum model that consists of only the first solvation shell embedded in a continuum dielectric medium capture all major features of the experimental results.

\subsubsection{Liquid water and methanol}

Both water and methanol are hydrogen-bonded liquids. The hydrogen-bond between the molecules is responsible for the physical and chemical properties of the liquid, although the H-bond is much weaker than conventional bonds (covalent). The effect of the H-bond is essential for the understanding of many chemical and biological systems. In liquid water, every water molecule can donate two and 


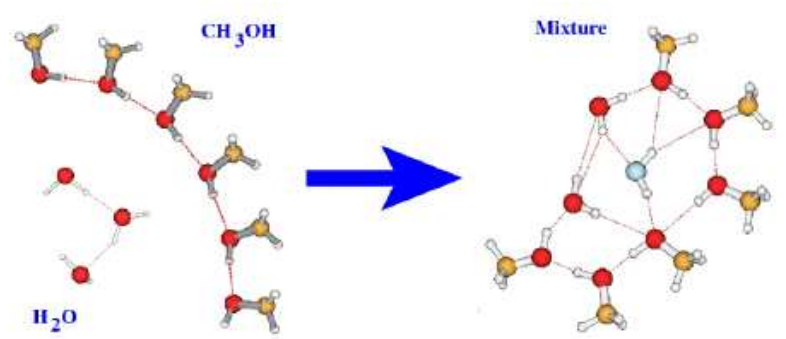

Figure 3.9: Mixing of methanol rings and water molecules.

accept two hydrogens building up the liquid network. These H-bonds frequently break and form which very with temperature and pressure.

The H-bond effect on the electronic structure of pure water is shown paper VIII and IX. In the study the change in electronic structure was observed when comparing the free water molecule to water in the liquid phase and the use of theoretical simulations. Upon liquidisation, the shape of the emission spectrum changes and a major intensity loss is observed at region corresponding to the bonding orbital $3 \mathrm{a}_{1}$ of the water molecule. The calculations show the major influence of the H-bonding on the local electronic structure is due to the first coordination shell, and that strong molecular orbital mixing among different water molecules occur that mainly affect the $3 \mathrm{a}_{1}$ orbital. The small proportion of mixing between molecules are interpreted as covalent bonding. Apart from the four-hydrogenbonding structure in water, a structure where one hydrogen bond is broken could be separated and identified.

In methanol every molecule can accept and donate one hydrogen to form $\mathrm{H}$ bonding. Mainly the oxygen-hydrogen part of the molecule takes part in the bonding. This has an big effect on the structure of liquid methanol and other alcohols. Structural studies of liquid methanol, using hard x-ray and neutron scattering, have suggested either chain or ring formation. Our soft x-ray emission study, in paper X, showed the existence of both rings and chains in the liquid phase and the dominating structures are formed of 6 and 8 molecules. The molecular orbitals of methanol in 6-chain and 6-ring formations, presented in paper XIII, shows a saturated hydrogen bonding structure for methanol rings, while the open structure of the methanol chain shows a strong polarization.

\subsubsection{Mixing of liquids and solutions}

The effect of molecular arrangements upon the electronic structure of water is also demonstrated in the study of salt solutions $\mathrm{NaCl}, \mathrm{MgCl}_{2}$, and $\mathrm{AlCl}_{3}$ (Paper XII). Spectral changes in the resonant $\mathrm{O} K$-emission was observed, due to rearrangements of the water structure around the ions, depending on the size and charge of the ions in the solution.

When methanol or ethanol is mixed with water, the entropy of the system increases far less than expected for an ideal solution (randomly mixed molecules). A resent neutron diffraction study suggested molecular segregation in alcohol-water 
solutions, which explained the low entropy [33]. The findings in paper $\mathrm{X}$ does not only provide additional evidence for segregation at the molecular level but also help to further refine the understanding of some structural features of wateralcohol mixtures. Upon mixing of water and methanol, a small x-ray absorption peak appears below the known absorption edge. This new feature suggest the interaction between water and methanol molecules. Resonant x-ray emission excited at the 'new' feature results in a narrow emission band, very different from spectra of pure water and pure methanol. Comparison between experiment and theory suggest formation of structures where water molecules interact with methanol chains. Upon mixing water and methanol chains would interact strongly with water clusters, making ordered rings structures out of methanol chains (see fig. 3.9). These

joint water-methanol-ring structures owns the explanation to loss of entropy of the solution.

\subsubsection{Detuning: Resonant Soft x-ray emission of water be- low the threshold}

The first studies of pure water concerned excitations at and above the absorption threshold. In paper ?? this was extended with excitations below the threshold. By doing so the duration time for the resonant x-ray scattering process can be extensively shorten. In normal emission the time is govern by the core hole lifetime, in the low femtosecond range $\left(10^{-15}\right.$ seconds). 


\section{Acknowledgements}

First of all I would like to thank Joseph Nordgren for giving me the opportunity to work in his group and for all the support during my years in the group. And I would like to thank Jinghua Guo, who I have been working mostly with during my time, for sharing his knowledge in the Soft x-ray field and for a good year in Berkeley.

I am also very grateful for help all support from the senior researchers Jan-Erik (Ruben) Rubensson, Laurent Duda and Sergei Butorin in the Uppsala Soft x-ray group, thank you very much.

A big thanks to the former graduate student Thorsten (Totte) Schmitt for all help and good collaboration in various projects. And also for being a good friend, the trips to New York and Las Vegas were a whole lot of fun. Many thanks to my college and friend Magnus (Uffe) Ström, unfortunately we never got work on any projects together, but we sure had a lot of fun anyway :-).

I would like to acknowledge the other members of the group; Conny Sathe, Marcus Agåker (The Warrior :-) ), Kristina Kvashnina, Johan Söderström (good luck in Berkeley), Martin Magnuson, Lars Werme, Johan Forsberg and former members, Tanel Käämbre and Limin Qian. Many thanks to the great engineer Carl-Johan (Calle) Englund, who also like old Fords, and our secretary Anne Kronquist, and Gunnel Ingelöq for all help with paper work. Thanks to Anders Henningsson, Hans Siegbahn, Leif Karlsson, Olle Björnholm and Svante Svensson from Fysikum. Thanks to the theoreticians from KTH, Luo Yi, Stepan Kashtanov, Barbara Brena and Hans Ågren. And theory team at Fysik IV Uppsala; Jorge Osorio Guillén, Rajeev Ahuja and Maurizio Mattesini (now in Spain). I would also like to thank the battery experts at the Dep. of Materials Chemistry, Marie Herstedt, Sara Nordlinder, Kristina Edström, and Torbjörn Gustafsson and Josh Thomas for a very good collaboration, it has been a great pleasure working with you. I acknowledge the people who worked at beamline 511 in Maxlab, Chris Glover, Dennis Nordlund and Lidia Gridneva for all help during experiments and maintenance. Thanks Chungli Dong for your help at beamline 7.0.1. at ALS. Vera Zhuang and Phil Ross at LBL are acknowledged for good collaboration and interesting discussions about the battery stuff. The guys in the workshop greatly acknowledged, especially Lasse who solved many mechanical problems. Thanks, ALS Fellowship Program with Zahid Hussain and ALS staff for the year in Berkeley. Thanks to Renee and Kitty (Mr. Cat) for the stay in Oakland and for all the good food :-), -hope i get to see the driveway some day.

And last but not least, many thanks to all my friends (Sorka, Uppsala gänget, 
mf) and my dear family. 


\section{Chapter 4}

\section{Summery in Swedish}

\subsection{Mjukröntgenspektroskopi av litium batterier och vätskor}

Elektronstrukturen för olika litium batteri material och några av våra vanligaste vätskor har undersökts med hjälp av mjukröntgenspektroskopi. Ett materials eller en molekyls egenskaper bestäms hur elektronerna är fördelade mellan de ingående atomerna d.v.s. elektronstrukturen. Atomerna binds ihop av dess yttersta elektroner (valenselektroner) som fördelas på ett energi fördelaktigt sätt som kan beskrivas av kvantmekaniken. De inre elektrontillstånden (kore-elektronerna) påverkas betydligt mindre av omgivningen och är väl separerade (i bindningsenergi) mellan olika atomslag. Man kan enkelt avgöra vilka atomslag som ingår i ett material eller en molekyl genom att undersöka bindningsenergierna för koreelektronerna. De små energiskift som uppstår pga. omgivningen kan förvisso uppmätas, men betydligt större förändringar sker i de yttre nivåerna. I röntgen absorption- och emission-spektroskopi är både kore- och valens-tillstånden involverade, så att den lokala elektronstrukturen kan studeras separat runt ett specifikt atomslag i ett material eller i en molekyl bestående av flera olika atomslag. I röntgen absorption undersöks de icke-tillsatta tillstånden genom att excitera en elektron från en inre nivå med en röntgenfoton. Det exciterade tillståndet kommer att inom någon femto-sekund att sönderfalla där samma elektron eller någon annan valenselektron fyller denna innerskalsvalens varvid en röntgenfoton sänds ut eller en annan elektron kastas ut ur systemet (Auger-sönderfall). I mjukröntgen området är foton kanalen betydligt svagare än Auger kanalen (ca. 100 - 1000 ggr svagare).

För denna typ av spektroskopi behövs starka ljuskällor, samt möjligheten att välja våglängd/energi. Röntgenstrålning av hög intensitet fås med synkrotronljuskällor, där strålningen produceras genom att elektroner med relativistiska hastigheter förlorar energi i ett magnetfält. En synkrotron anläggning består enkelt av en stor accelerator ring och ett antal långa strålrör som leder ut strålningen till de olika experimentstationerna. Strålrören består av gitter och diverse speglar och spalter för att välja ut energi samt fokusera strålning vid experimentstationen. För att inte 
strålningen ska absorberas på vägen fram till provet är hela anläggningen under vakuum. Dessa anläggningar finns runt om i världen, här presenteras mätningar som gjorts vid MAX-lab i Lund samt vid ALS i Berkeley, Kalifornien.

Spektrometern, som används i detta arbete, är en gitterspektrometer som bygger på Rowland-geomerti, där samtliga optiska ingående element (ingångsspalt, gitter, och detektor) är anordnade längs en cirkel. Ingångsspalten och gittrena är fast monterade meddans den tvådimensionella detektorn kan flyttas för att nå olika energi-intervall. Gittrena är ofta tillverkade av glas med många parallella ritsar (skåror) och belagt med något tungt grundämne så som guld eller platina.

Litium batterier används i vårt dagliga liv, som i mobiltelefoner, digitalkameror samt portabla datorer. Denna typ av uppladdningsbara batterier har funnits på marknaden sedan början av 1990-talet och har många fördelaktiga egenskaper såsom hög spänning, stor energilagringskapacitet och lagringstid. Batterierna består av en katod (positive elektrod), en anod (negativ elektrod) samt elektrolyt med innehållande litiumsalt för jontransport. Litiumjonerna i elektrolyten fungerar som laddningsbärare mellan elektroderna under i- och ur-laddning av batteriet. Då litiumjonerna går in i elektroden överförs även elektroner till elektrodmaterialet vilket förändrar elektronstrukturen i materialet. Elektron strömmen som uppstår under urladdningen anvä nds för att driva elektroniska kretsar i t ex. mobiltelefonen. Andra sidoreaktioner kan även ske inuti batteriet under i- och ur-laddnings processen. På anoden bildas ett mellanskikt mellan anoden och elektrolyten genom att vissa av molekylerna i elektrolyten reagerar med litiumjoner och bildar andra föreningar som fastnar på elektroden. Dessa olika processer har studerats med mjukröntgenspektroskopi. Elektronstrukturen har undersökts för olika övergångsmetalloxider (vanadin, titan och järn) som katodmaterial. Laddningsöverföringen har studerats som funktion av litium-innehåll i materialet, där elektroner överförs till lediga metall-d-tillstånd. I vissa fall har även teoretiska beräkningar utförts för jämförelse med uppmätta data. På anod sidan har den vanligaste förkommande materialet grafit undersökts.

Vatten är vår vanligaste och viktigaste vätska här på jorden. Vatten molekylerna är sammanfogade med vätebindningar, som är en svagare bindning än den kovalenta bindningen som håller ihop syret och de två väteatomerna i vatten molekylen. Dessa vätebindningar, som bygger upp vattnets struktur, har studerats men dess natur är än idag inte helt utrett. De flesta studier har behandlat vattens struktur där olika diffraktions experiment har genomförts. Med hjälp av dagens snabba datorer har man även gjort dynamiska simuleringar för att studera olika strukturer och hur vätebindningarna bryts o formas. Vattens elektronstruktur har dock inte studerats lika frekvent, mesta dels p.g.a. experimentella begränsningar, som hur man hanterar vätskor i vakuum system. Idag har man löst detta med hjälp av väldigt tunna och starka röntgenfönster som separerar vätskan från övriga vakuumsystemet men som ändå släpper igenom röntgenstrålarna. I denna avhandling presenteras de första mjukröntgen emission spektrumen av vatten (i flytande form), där en liten cell med ett $1000 \AA$ tunt fönster har använts för att innesluta vätskan. Studien kunde jämföras med studier av fria vatten molekyler (vattenånga) samt kvantmekaniska beräkningar. Beräkningarna och experimenten visade hur de olika valensorbitalerna i vatten molekylen påverkas av vätebindningarna och en viss kovalent karaktär hos vätebindningen har påvisas. Resonant röntgen-emission visade 
även förekomsten av brutna vätebindningar av en viss symmetri, som tidigare hade påvisats ur röntgen absorption studier. Den enklaste alkohol molekylen metanol (träsprit) kunde också studeras med samma teknik samt undersöktes vad som händer när man blandar alkohol och vatten. I ren metanol kunde strukturer av kedjor och ringar påvisas uppbyggda av 6 och 8 metanol molekyler som hålls ihop med vätebindningar. Tidigare studier som bygger på diffraktions mätningar hade förslagit antingen kedjor eller ringar beroende på hur man tolkade (ibland samma) data. Här såg vi båda strukturerna i ungefär lika proportioner. Då man blandar alkohol och vatten har man tidigare trott att dessa vätskor blandar sig på en mikroskopisk nivå , men entropin (oordningen) för systemet ökar inte som förväntat för en sådan blandning. En senare studie har visat att detta beror på att dessa två vätskor inte riktigt blandar, utan att alkoholen och vattnet istället bildar små separerade kluster i lösningen. Vår studie visade också på detta, men även hur metanolkedjor och vattenmolekyler kan sammanfogas, med vätebindningar, och bilda ringar. Såna ordnade strukturer tillsammans med segregationen leder till att entropin för systemet sjunker. Etanol (som kan drickas) har liknande egenskaper och förväntas fungera på samma sätt; 'shaken or stirred' spelar ingen roll! 



\section{Bibliography}

[1] David Attwood. SOFT X-RAYS AND EXTREME ULTRAVIOLET RADIATION: Priciples and Applications. Cambridge University Press, Cambridge, UK, 1999.

[2] Sergei M. Butorin. J. Electron Spectrosc. Relat. Phenom., 110-111:213, 2000.

[3] J. A. Carlisle, E. L. Shirley, E. A. Hudson, L. J. Terminello, T. A. Callcott, J. J. Jia, D. L. Ederer, R. C. C. Perera, and F. J. Himpsel. Phys. Rev. Lett., 74:1234, 1995 .

[4] J. A. Carlisle, E. L. Shirley, L. J.Terminello, J. J. Jia, T. A. Callcott, D. L. Ederer, R. C. C. Perera, and F. J. Himpsel. Phys. Rev. B, 59:7433, 1999.

[5] A. Dobley, K. Ngala, S. Yang, P. Y. Zavalij, and M. S. Whittingham. Chem. Mater., 13:4382-4386, 2001.

[6] W. Ederhardt, I. T. McGovern, E. W. Plummer, and J. E. Fisher. Phys. Rev. Lett., 44:200, 1980.

[7] Th. Fauster, F. J. Himpsel, J. E. Fischer, and E. W. Plummer. Phys. Rev. Lett., 51:430, 1983.

[8] T. Gustafsson, J. O. Thomas, R. Koksbang, and G. C. Farrington. Electrochim. Acta., 37:1639, 1992.

[9] C. S. Fadley Z. Hussain H. Bluhm, D. F. Ogletree and M. Salmeron. J. Phys. Condens. Matter, 14:L227-L233, 2002.

[10] A. Hagfeldt, N. Vlachopoulos, and M. Grätzel. J. Electrochem. Soc., 141:L82, 1994.

[11] S. Y. Huang, L. Kavan, I. Exnar, and M. Grätzel. J. Electrochem. Soc., 142(9):L142, 1995.

[12] K. Waltersson K. A. Wilhelmi and L. Kihlborg. Act. Chem. Scan., 25:2675, 1971.

[13] B. S. Rude R. D. Schaller A. Nilsson L. G. M. Pettersson N. Goldman T. Catalano J. D. Bozek K. R. Wilson, M. Cavalleri and R. J. Saykally. J. Phys. Condens. Matter, 14:L221-L226, 2002. 
[14] T. Catalano J. G. Tobin D. T. Co K. R. Wilson, B. S. Rude and R. J. Saykally. J. Phys. Chem. B, 105:3346-3349, 2001.

[15] J. Kim and A. Manthiram. Electrochemical and Solid State Letters, 1:207, 1998.

[16] P. Kirkpatrick and A. V. Baez. J. Opt. Soc. Amer., 38:766, 1948.

[17] A. Kotani. J. Electron Spectrosc. Relat. Phenom., 110-111:197, 2000.

[18] F. Krumeich, H.-J. Muhr, M. Niderberger, F. Bieri, B. Schnyder, and R. Nesper. J. Am. Chem. Soc., 121:8324, 1999.

[19] H. Ogasawara A. Nilsson L. G. M. Pettersson Ph. Wernet D. C. Edwards M. Sandström L. Å. Näslund, M. Cavalleri and S. Myneni. J. Phys. Chem. A, 107:6869-6876, 2003.

[20] Y. Luo, H. Ågren J.-H. Guo, P. Skytt, N. Wassdahl, and J. Nordgren. Phys. Rev. A, 52:3730, 1995.

[21] Y. Ma and P. D. Johnson. Phys. Rev. B, 49:5024, 1994.

[22] Y. Ma, N. Wassdahl, P. Skytt, J.-H. Guo, J. Nordgren, P. D. Johnson, J.-E. Rubensson, T. Böske, W. Ederhardt, and S. D. Kevan. Phys. Rev. Lett., 69:2598, 1992.

[23] D. W. Murphy and P. A. Christian. Science, 205:651, 1979.

[24] I. A. Nekrasov, K. Held, N. Blümer, A. I. Poteryaev, V. I. Anisimov, and D. Vollhardt. Eur. Phys. J. B., 18(1):55-61, Nov 2000.

[25] Yoshio Nishi. J. Power Sources, 100:101, 2001.

[26] J. Nordgren, G. Bray, S. Cramm, R. Nyholm, J.-E. Rubensson, and N. Wassdahl. Rev. Sci. Instrum., 60:1690, 1989.

[27] S. Nordlinder, K. Edström, and T. Gustafsson. Electrochemical and Solid State Letters, 4:129, 2001.

[28] B. O'Regan and M. Grätzel. Nature (London), 353:737, 1991.

[29] W. B. Peatman. Gratings, Mirrors and Slits: Beamline Design for Soft Xray Synchrotron Radiation Sources. Gordon and Breach Science Publishers, Amsterdam, Netherlands, 1997.

[30] E. Peled. J. Electrochem. Soc., 126:2047, 1979.

[31] P. Poizot, S. Laurelle, S. Grugeon, L. Dupont, and J. M. Tarascon. Nature, 407:496, 2000.

[32] J. M. Reinoso, H.-J. Muhr, F. Krumeich, F. Bieri, and R. Nesper. Helv. Chim. Acta, 83:1724, 2000. 
[33] W. C. K. Poon J. L Finney S. Dixit, J. Crain and A. K. Soper. Nature, 416:830-832, 2002.

[34] L. Å. Näslund M. Cavalleri L. Ojamäe H. Ogasawara A. Pelmenschikov Ph. Wernet P. Väterlien C. Heske Z. Hussain L. G. M. Pettersson S. Myneni, Y. Luo and A. Nilsson. J. Phys. Condens. Matter, 14:L213-L219, 2002.

[35] J.J. Sakurai. Advanced Quantum Mechanics. Addison-Wesley, London, UK, 1967.

[36] J. A. R. Samson. Techniques of Vacuum Ultraviolet Spectroscopy. Wiley, New York, 1967.

[37] W. Schülke, Berthold, Kaprolat, and H.-J. Güntherodt. Phys. Rev. Lett., 60:2217, 1988.

[38] Northampton Road Bilsworth Northhampton NN7 3DW England Silson Ltd, JBJ Business Park. peter.anastasi@silson.com.

[39] P. Skytt, P. Glans, D. C. Mancini, J.-H. Guo, N. Wassdahl, J. Nordgren, and Y. Ma. Phys. Rev. B, 50:10457, 1994.

[40] M. E. Spahr, P. Bitterli, R. Nesper, M. Müller, F. Krumeich, and U. H. Nissen. Angew. Chem. Int. Ed., 37:1263, 1998.

[41] J. Stöhr. NEXAFS Spectroscopy, volume 25 of Springer Series in surface Science. Springer-Verlag, Berlin Heidelberg, 1992.

[42] T. Warwick, P. Heimann, D. Mossessian, W. McKinney, and H. Padmore. Rev. Sci. Instrum., 66:2037, 1995.

[43] A. H. Whitehead, J. M. Elliot, and J. R. Owen. J. Power Sources, 33:81-82, 1999. 